\title{
EXPLORING HYBRIDITY AND IDENTITY NEGOTIATION OF YOUNG TAMIL CANADIAN WOMEN: AN AUTOETHNOGRAPHIC STUDY
}

\author{
by
}

Angeline Sahayanathan (BA Honours), Ryerson University, 2018

A Major Research Paper

presented to Ryerson University

in partial fulfillment of the requirements for the degree of

\author{
Master of Arts \\ in the Program of \\ Immigration and Settlement Studies
}

Toronto, Ontario, Canada, 2019

(C)Angeline Sahayanathan 2019 


\section{AUTHOR'S DECLARATION FOR ELECTRONIC SUBMISSION OF A MAJOR RESEARCH PAPER (MRP)}

I hereby declare that I am the sole author of this MRP. This is a true copy of the MRP, including any required final revisions, as accepted by my examiners.

I authorize Ryerson University to lend this MRP to other institutions or individuals for the purpose of scholarly research

I further authorize Ryerson University to reproduce this MRP by photocopying or by other means, in total or in part, at the request of other institutions or individuals for the purpose of scholarly research.

I understand that my MRP may be made electronically available to the public. 


\title{
Angeline Sahayanathan \\ Master of Arts, 2019 \\ Immigration and Settlement Studies \\ Ryerson University
}

\begin{abstract}
This paper presents an autoethnographic analysis of hybridity and identity negotiation related to young Tamil Canadian women. Tamil women face unique challenges when it comes to maintaining cultural practices that are so heavily embedded in our upbringing. I have experienced this within my own life, in addition to observing similar challenges among women whom I have encountered within the Sri Lankan Tamil community in the City of Toronto. Young Tamil Canadian women are finding it difficult to conform to cultural expectations given their upbringing in a Western country like Canada. Using an autoethnographic approach, the purpose of this paper is to examine transnational issues young Tamil Canadian women - specifically daughters, experience in their diaspora, as a result of negotiating between cultural practices and related impacts or consequences. Specifically, I employ vignette writing, a form of creative analytic practice to explore how young Tamil women are seen as carriers of culture and related implications for their agency and autonomy. Further, I examine and communicate how personal negotiations related to choosing to follow certain Tamil cultural practices and rejecting others, can result in community isolation, rejection from diasporic relations, and uncertainties about self-worth. I consider processes of identity construction and negotiation, and how this results in the creation of a third space that celebrates difference through new ways of being, encompassing cultural values from both the Canadian and Sri Lankan Tamil spectrum. My lived experiences will translate into short narratives that create a tangible example of this phenomenon and is captured by theories of hybridity, third space, acculturation and the good daughter.
\end{abstract}

Key words: Diaspora, hybridity, identity, negotiation, culture, practices, gender, roles, migration, daughters 


\section{Acknowledgements}

my voice is the offspring

of two countries colliding

what is there to be ashamed of

if English and my mother tongue

made love

my voice is her father's words

and my mother's accent

what is the matter if

my mouth carries two worlds

accent - Rupi Kaur

First and foremost, I would like to thank God for helping me reach the ending of this journey.

His grace sustained me. This entire year thus far has been unimaginably hard - experiencing pain and trauma in ways I wish I didn't have to. But His promises and words remained true in my life, and that is how I stand today. Through all the nights of anxiety inducing thoughts, I was able to pour out my words and beliefs onto this paper. To all who read, Tamil or not, female, male and/or other, I hope this paper speaks to you and allows you to embrace your space in between.

I would like to thank my supervisor, who has now become a true friend, mentor and inspiration to me - Dr. Sara Edge. You have seen me grow from a young lady to a strong independent woman. You showed me how to fall in love with education and the academic realm. Your classrooms became a warm place to me - I am forever grateful for the space you have provided for me to learn, grow and develop in. You believed in me and rooted for me. I am where I am because you saw potential in me. It's not about the journey but who you travel with. Your patience and continuous leadership are evident through every single line of this paper. I hope to make you proud.

Thank you, to my Sahayanathan's. I will never forget the day I came back to Scarborough after a long day of school, and you were all sleeping in the car waiting to pick me up. I tell you 'I can bus home!' but your sacrifices every night have given me the strength to wake up the next morning. I am so blessed and fortunate to have a family who supports my dreams even when there are days you don't understand it. To my sweet sister - you are my security, my backbone, my gem; thank you for loving me and supporting me, for teaching and praying for me. I love you.

Thank you, Halcyon, - this last year would not have been possible, nor doable, without your kindness and support towards me. This is for you - the voice you helped me find. I would not be here if you didn't take my hand and walk with me. Forever grateful. 


\section{Table of Contents}

Author's Declaration for Electronic Submission of an MRP .................................. ii

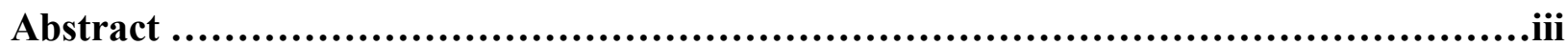

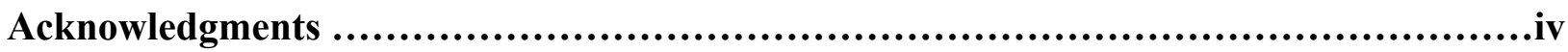

Chapter 1: Introduction ............................................................... 1

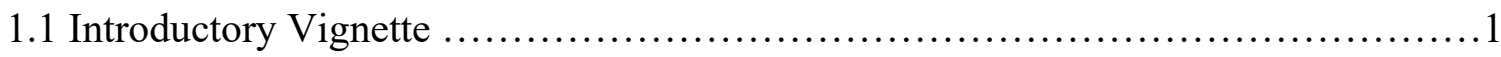

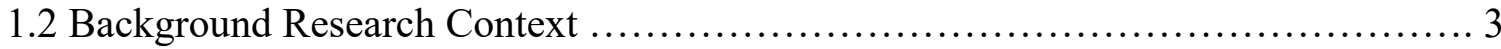

1.2.1 Birth of Identity and Trauma ......................................... 3

1.2.2 Hybridity and Identity Negotiation ................................ 5

1.3 Objectives ................................................................ 6

Chapter 2: Literature Review ........................................................... 8

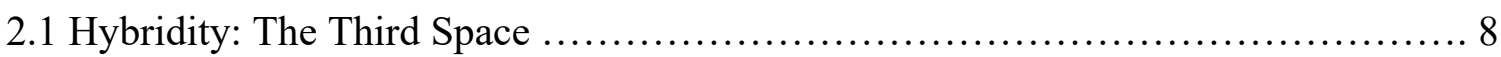

2.2 Acculturation, Multiculturalism and the Dialogical Self ...................... 10

2.3 Roots of the "Good" Tamil Daughter ....................................... 12

2.3.1 Tamil Daughters as Carriers of Culture ................................ 15

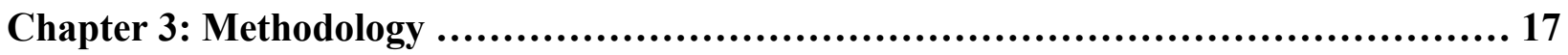

3.1 Research Approach ........................................................ 17

3.2 Vignette Writing ............................................................ 19

3.3 Approach to Vignette Construction ....................................... 22

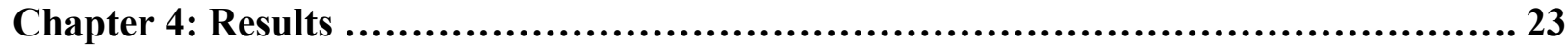

4.1 Psychosocial and Maturation Milestones of Angeline Sahayanathan .............. 23

4.2 Vignettes ........................................................... 26

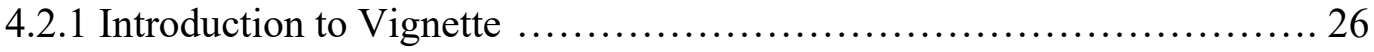

4.2 .2 Who are you? ................................................... 26

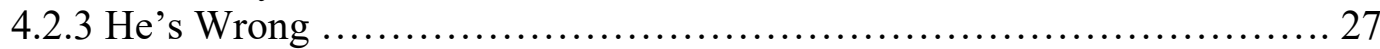

4.2.4 40 Days and 40 Nights ....................................... 28

4.2.5 Discovering the Third Space and the Cultural "Other" .................. 31

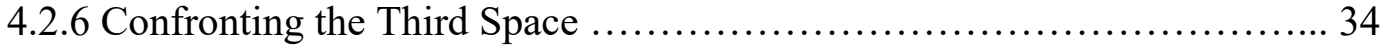

Chapter 5: Discussion ...................................................................... 40

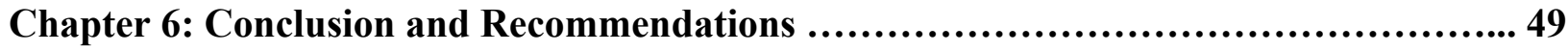

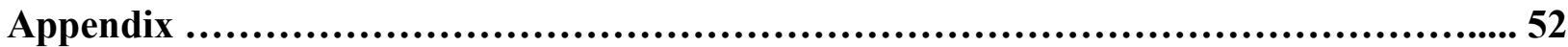

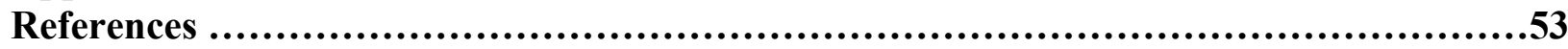




\section{CHAPTER ONE}

\subsection{Introductory Vignette}

'You know - you should tell me things', and I was like, well yeah, and I know you're not stupid, I know you know I don't tell you anything. Well not anything, I don't tell you everything. Some things I won't even tell Akka, because I'm more of a private person, I like keeping things to myself. I remember one time I was drawing in my sketchbook, and I didn't wanna show Amma right? ... and I was like sitting there, and I closed it, and I was like 'no I don't wanna show you it', and she got so mad at me, so she literally ripped the sketchbook from my hands and goes to the master bedroom and starts yelling to Appa 'Our child doesn't wanna show me her drawings' and Appa was like 'that makes sense!' Everyone was like 'that makes sense!'. And then Amma gets touchy, and is now like, 'everyone's against me'... like, shut up, you shouldn't have taken it in in the first place.

Our moms victimize themselves, just because we say no. It's not like we're hiding anything from them, there's just some things we don't want to share, and rather keep to ourselves. I think it's because they grew up with no privacy. They grew up with their uncles, their aunts, their cousins, their brothers. Everyone's up in your business, trying to shape you into something that will cater to everyone and not your own self. That's why our parents want us girls to be fully transparent with them; that's how they were raised.

I don't think that's fair.

They don't understand that if they weren't so pushy, maybe we would be more open with them. But the thing is, practically everything Amma knows about my high school friends is not because I told her, it's because she had access to all my messages/accounts.

'Do you think it's because we're Tamil girls'?

Yes.

Part of it. Absolutely. White people don't grow up like this. I think ... it's definitely cultural. Yeah, I don't think our parents realize how much pressure there is just being in this culture. It's very ... I don't want to say it's toxic because there are good aspects of it but like, if you think about it, we don't focus on the good aspects. We only focus on how everyone's like - oh she dropped the sciences?? She's not a good child. She wears shorts, she's not a good child.

One of the main issues is that they're trying to raise us how it was there. But there, everyone is being raised like that. So even if it is a lot of pressure, you're not different. Back home in Sri Lanka, you have other girls going through the same thing, so it's fine. But when you're here, being raised as a daughter in that exact SAME way, when everyone else is being raised DIFFERENTLY that's when the issues really start to pop up. I know there's the whole big thing about trying to keep our culture in this place, which is good, but you still have to adapt to a certain extent. 
Certain aspects of our culture are phenomenal. Like, I love how we're so family oriented, and I love that there's respect for elders and others that happens naturally. But disciplining your daughter by guilt tripping them, or by making them feel like they're inadequate, is not okay.

Neither is the lack of respect for privacy. For instance, telling someone something confidential, something just for them, but then all of a sudden, every aunt knows. It's so annoying! There was this one thing I got so mad at Amma about - it was about my kidney stone issue. I told her NOT to tell anyone, but what does she do?... the whole Church knows. But she was like 'oh they're just going to pray for you'. I DON'T CARE if they're just going to pray for me -if it's my business I should be in control of my life.

It's not just Amma, it's in general. If it's your child, it's your issue. But at the same time, they say 'deal with your own issues'. If your teacher is being unfair to you, they're gonna be like 'that's on you'. We girls just gotta take care of ourselves. We have to deal with these issues on our own - conflict at school, at work, with our friends. We have our own backs. But when it comes to more minor trivial things like 'why are you smiling at your phone' or 'why are you wearing that shirt', or 'you shouldn't hang out with people who aren't related to you'... that's when they want to get up in our face. If this was me talking to someone else who wasn't you at this time of night, or we didn't just leave our cousin's house at $10 \mathrm{pm}$, our phone would have blown up like 'Where are you! What are you doing! It's almost 10, come home.' Appa texts me from 9:30 pm on, like, when are you home when are you home when are you home. That makes me want to stay out longer. I'm 23 years old, you're 25, you're a grown woman - why do we have these restrictions?!

How does it feel when I'm with my girlfriends who are not Tamil? Who don't understand our culture or these rules? My non-Tamil friends will never learn the full extent, but they partially understand because I had to tell them upfront my parents see everything. My Tamil friends are more flexible - that's because they're Tamil girls and they just get it. But it's different with my all-white Church. Different? How? Well, they make plans on the spot - 'oh, let's go out to dinner!' But I'm not even gonna bother asking my parents because I already know what they're gonna say “பெண்கள் இரவில் தாமதமாக வெளியே செல்லக்கூடாது, வீட்டை விட்டு வெளியேறக்கூடாது - girls should not go out late at night and leave their house.

And it's not just a cultural thing because there's this one brown family who let's their son go out all the time because he's dating one of the girls in that group. Imagine it was a Tamil girl in that situation? We all know that we would never be accepted if that was us. The Tamil community that surrounds us, has mostly sons. And these guys just don't understand us. They're so different. This is weird to say but they don't even eat their food with their hands like us ... they're just super westernized. That's why they can't relate. They say stuff, and I pretend to relate but I can't relate. My life is, I wake up, I go to school, I come back home, I study, I watch Netflix, I don't go out with friends, I just stay home. I can't relate to them. I'M TRYING BUT I CAN'T.

I'm telling you - it gets better. It gets better because I just found a way to do more. I lie. I remember being 16 or 17, thinking like, I'm never getting out, I'm never getting out. But once you get your license, and since our parents are gone to work most of the day, and I have access to 
a car, I can do more. I can go to the mall whenever I wanna go to the mall, I can meet up with my friend for lunch when I wanna meet up. And, I'm not necessarily telling my parents all these things that I'm doing, but I can still do them because I'm earning my own money, I don't have to report my spending back to my parents. I know it's not the best thing to do, but university was my window of hope. I used to love commuting downtown and back to Scarborough. Sometimes I would tell my parents I have class 9 am to 9 pm, when really, I only had a 9-10 am class. But for the rest of the day, I could just chill with my friends and go out and have fun.

I don't encourage lying but I finally felt like my own person. I'm just saying sometimes you just need to try to fight for yourself, and that's literally what I've been doing for so long now.

Sober nights with my sister ft. our thoughts

\subsection{Background Research Context}

I find it necessary to state that this major research paper uses an introspective, arts-based approach that challenges traditional conventions of academia in an attempt to make scholarship more accessible and to provide an opportunity to amplify the voice and lived experience of a young Tamil woman and migrant to Canada. My study illustrates and connects personal experiences/narratives to key theoretical concepts found in the academic literature. Personal experience methods offer a new and unique vantage point from which to make a contribution to social science

\subsubsection{Birth of Identity and Trauma}

I was born and raised in Toronto, which houses the second largest diaspora of Sri Lankan Tamils in the world, after the city of London, England (Hyndman, 2016). Expansion of the Tamil diaspora in Toronto occurred during the major influx of Tamil refugees from Sri Lanka due to civil war between 1983 to 2009. According to the Canadian census, as of 2016, there are 117,630 Tamils living in the province of Ontario with nearly half of that population, $(57,535)$, reported to be living in the city of Toronto (Statistics Canada, 2019).

Tamils immigrated to Canada due to fear of cultural genocide and ethnic cleansing by the Sinhalese government. The Civil War impacted how Tamil culture was able to flourish in Sri Lanka forcing many, including my relatives to seek refuge in Canada. Compelled to migrate out of Sri Lanka after the Civil War, many thousands of Tamils lived as refugees and asylum seekers and continue to live as Canadian citizens and/or duo-citizens. Though Tamil migrants are dispersed all over the world, the diaspora in Canada is of particular interest due to their strong 
long-distance nationalism to Sri Lanka. This has been achieved through the close-knit Tamil diaspora in Canada establishing various cultural organizations, which helped in the strengthening of community ties.

Collective cultural trauma has arisen as a result of the dignity and safety of the Tamil culture becoming endangered and undermined - within both our home country, and in Canada. Tamil immigrants had to let go of certain cultural practices to assimilate into Canadian society. During this process, many felt they lost a part of their identity (Grønseth, 2018). Tamils carefully considered appropriate practices, values and needs amid calculations of the risk of exposing what could be regarded as their 'exotic Tamilness' (Grønseth, 2018). Given how an emphasis on their 'Tamilness' could increase their profile as 'other', many feared the risk of increasing their stigmatisation and marginalisation by the local Canadian community. In the face of fleeing a shared trauma, especially one that threatens a community's identity and security, the Tamil diaspora has attempted to hold on to ideas of cultural purity (Satkunam, 2017). With a desire to oppose assimilation into a host country, many diaspora members have attempted to resurrect the Tamil culture in new countries to ensure their shared history is not lost. The need to protect their culture can be seen as a result of the trauma they faced in their homeland, and the fear that their identity will be weakened in a new home (Satkunam, 2017).

Interactions between family members is one site where community or generational trauma is discussed and inherited by the next generation as memories are shared (Satkunam, 2017; Hirsch, 2012). Trauma can move beyond an individual's life, and impact a community as a whole (Satkunam, 2017). First-generation Tamil parents fear the Tamil culture will be forgotten as their children assimilate to Canadian norms. Women in particular, are pressured as they are seen as carriers of culture. As carriers of culture, daughters are not afforded the same level of agency - and personal choice or autonomy in certain situations in comparison to Tamil sons (Satkunam, 2017).

There is an expectation for Tamil daughters to conform to and follow all cultural practices such as participating in language classes, puberty ceremonies, marrying young, religious activities, etc. Generally, there is particular concern over the "good reputation" of daughters because they are the "flag bearer of [our] culture" (Tyyska, 2005). The struggle to conform to their parents' expectations has led to a "rebellious movement" (Gowrinathan, 2012), 
where many young Tamil Canadian women reject certain cultural practices that they find oppressive or that do not align with their westernized choice of living. Examples of cultural practices Tamil daughters often find challenging include, abiding by a curfew, participating in a puberty ceremony, wearing cultural clothes (sarees) to every family gathering/abiding by a dress code, mandatory expectation to put together cultural ethnic meals, agreeing to marry before the age of 25 , and having a child before the age of 30 . The backlash that can be received from the migrant community as a result of their choices, has become a stressful/emotional barrier to their well-being, and an influence upon self-worth and identity (Gowrinathan, 2012).

The voices of Tamil women are often lost in cultural interpretations of nationalism towards our home country, Sri Lanka (Grønseth, 2017). I can personally attest that my voice is often unheard in my diasporic community, and as a result, my narratives are lost. This is not an uncommon issue, as this feeling resonates with many of my same age/gender Tamil friends and relatives. We are taught to keep our feelings and choices internalized; we are warned if exposed, we will be shunned by our diasporic community. As people move and migrate, cultural practices and gender roles are taken to new locations and assume old/new values and meanings, thus informing negotiable identities (Svašek \& Skrbiš 2004). It is important to understand how the diaspora in Canada define their post-migration experience to Canada, and how the experiences might vary between gender and generations.

\subsubsection{Hybridity and Identity Negotiation}

Feeling stuck between two cultures can create confusion and conflict: your family wants one thing, and you want something that is diametrically opposite. As is very common for other immigrant women, Tamil Canadian young women, exposed to a multicultural country like Canada, may (a) feel stuck between two cultures, (b) find it hard to see eye-to-eye with their parents on many things, because of opposing cultural views, and/or (c) experience conflict with family/cultural group (Choi et. al., 2008). Choi et al (2008) have observed this pattern within Vietnamese and Cambodian immigrant families. Their study provides context on "intergenerational cultural dissonance (ICD) - a clash between parents and children over cultural values" (85). They state that this is a frequent issue for Asian [North] American youth (Choi et. al., 2008). Others have documented similar challenges that are difficult to manage between first 
generation Tamil parents and their children including, language barriers (if they don't speak English very well), different opinions on things (such as discipline, curfews or social outings), dating someone from a different culture/religion, and responsibility overload as daughters are predominately in charge of helping parents assimilate to foreign Canadian norms (Sinnathurai, 2005). As a result, young Tamil Canadian women feel different from European/white girls who represent the dominant, "less oppressed", "less restricted" culture. This can result, in young Tamil women distancing themselves from their parents' culture as it becomes so irreconcilable to the society, they are living in. Literature on parent-adolescent relations in the Toronto Tamil community points to the unstable well-being of Tamil female youth, who often feel torn between the desire to fit in with their peers and their desire to meet their parents' expectations which can lead to mental problems - depression, anxiety and low self-esteem (Barber \& Delfabbro, 2000).

In an attempt to maintain Tamil customs like language and religion, nationalists (first generation immigrant parents) look to their daughters in their future roles as mothers and wives (Grønseth, 2017). The roots of this come from the traditional Hindu construct of the 'good woman' as one who is married and auspicious (sumangali) (Grønseth, 2017). The construction of the Tamil wife is inextricably linked to a construction of the mother figure, which is often relied on as a symbolic representation of national and communal identity in South Asia [Sri Lanka] (Rajinisingham-Senanayake, 2001). That responsibility is pressurizing for many young Tamil Canadian women. Failure to acquire fluency in the Tamil language, rejecting weekly visits to the Temple, an unwillingness to celebrate 'womanhood' through puberty ceremonies may all contribute towards social exclusion experienced by young Tamil Canadian females from their diaspora. The need to resolve this social problem among our diasporic community and familial relationship(s) is vital for the mental health and stability of Tamil daughters. This requires giving more opportunity for Tamil women's voices to be more visible and heard.

\subsection{Objectives}

The intent of this paper is to give voice to and theorize my cross-cultural journey through revealing a series of challenging and triumphant episodes from my childhood, teen-hood and early-adult/womanhood from my life as a Tamil Canadian in Scarborough, an inner-city suburb 
of Toronto, a journey during which I have experienced both privilege and oppression and pressure to "be a certain way".

Using an arts-based auto-ethnographic approach, this paper will examine the following questions:

1. How does cultural hybridity influence how young Tamil Canadian women select/reject certain cultural practices?

2. What is the impact of their choices on familial/community relationships?'

To what degree do existing theoretical concepts - e.g. hybridity theory, cross-cultural psychology, third-space - adequately capture my lived experiences in navigating hybrid crosscultural identifies?

The objective is to theorize and creatively illustrate how the concept of hybridity illuminates my lived experience of identity performed across cultures, and more specifically, in a diasporic context. I explore my hybrid selfhood as a "critical nexus" (Alexander, 2014), blending various layers of my identity simultaneously: Tamil, female, second generation immigrant, daughter, and so on to assess the impact of my choices on familial/community relationships. I demonstrate how the complexities of my intersectional identity expand on and/or challenge the preservation of Tamil cultural practices within the Canadian context.

This autoethnography will give voice to factors that control my personal development, educational and life trajectory due to the high responsibility to learn and carry my culture in a city where Tamil immigration was newly emerging, and its culture was being reborn. Using creative analytic practice, and specifically vignette writing, the goal is to accessibly communicate processes of identity construction and the negotiation and creation of a 'third space' that celebrates new ways of being, encompassing cultural values from both the Canadian and Sri Lankan Tamil spectrum (Pindi, 2018). The process of creating a third space is articulated through different ways of being/not being "Canadian" and/or "Tamil" enough and/or just being "different." 
In order to address the key research questions, I utilize personal critical vignettes (explained in the methods) to interrogate the challenges Tamil Canadian women face when rejecting their positionality as a carrier of culture. Each vignette entry will align with existing theoretical concepts such as, hybridization and the third space that capture the lived experiences of young Tamil Canadian women. Using vignette entries to illustrate these theoretical concepts helps to communicate them in more accessible terms and enhances their meaning by infusing it with a lived experience perspective.

A central part of this study demonstrates how, in particular, Tamil daughters meet shifting challenges related to the ways in which social structures and cultural ideologies shape their lives and affect their sense of womanhood and subjective identity (Geller \& Stockett 2006; Grønseth, 2013). The feminist attention to individual variability, issues of power, and forces of social and cultural change is addressed by my narrations that display personal experiences of relative isolation, powerlessness and disgrace (Mahler \& Pessar, 2001; Grønseth, 2013). Thus, the paper can be seen to contribute to our understanding of the experiences of contemporary gendered migration, with the hope of contributing new creative, unique, 'daughter'-centered interpretations of migrant experiences of identity and belonging (Pedersen \& Rytter, 2018).

\section{CHAPTER TWO}

\subsection{Literature Review}

\subsection{Hybridity: The Third Space}

At a basic level, hybridity refers to any mixing of east and western culture. Within colonial and postcolonial literature, it most commonly refers to colonial subjects from Asia or Africa who have found a balance between eastern and western cultural attributes (Singh, 2009). Hybridity defined as 'cultural mixing' in general does not help us explicitly account for the many different paths by which someone can come to embody a mix of eastern and western attributes, nor does it differentiate between people who have consciously striven to achieve a mixed or balanced identity and those who accidentally reflect it (Singh, 2009). It seems important to note that there can be very different registers of hybridity, from slight mixing to very aggressive instances of culture-clash (as in the case explored on Tamil Canadian daughters). 
Wake's research (2018) informs and assists educators and academics who seek to further understand culturally diverse complexities within specific hybrid cultures compared to that of a monoculture (Wake, 2018(. Wake (2018) expresses the depiction of the predicament for Italian migrant women and their prophesied life by Vasta (1995) which consisted of the edicts firstly to marry an Italian man, secondly, to meet the imperative of being a virgin before marriage and thirdly, to maintain Italian cultural and social practices. It is with these strict cultural and religious stipulations that her parents adhered to living their new life in Australia and in turn endured oppressive racism within both the Italian and Australian communities consequently influencing and shaping a hybrid cultural life (Wake, 2018).

Pindi (2018) uses hybridity to theoretically conjugate her lived experience as an African woman of Congolese culture in America. She critically explores the political implications of her hybrid self, performed within the "third space" (Pindi, 2018) as a way of celebrating difference and new ways of being. By doing so, she creates a discursive space to explore how her hybrid identity has been shaped across two different cultures: the Congo and the United States. Similarly, authors Bardhan (2011) and Bhabha (1994) argue that an important feature of cultural hybridity is the creation of a third space "carrying the potential to generate new forms of identity for marginalized and culturally displaced subjects" (24) - representative of young Tamil Canadian women in Toronto who struggle to navigate and negotiate their identities.

Grossberg (1996) contends that "images of a 'third space' see subaltern identities as unique third terms literally defining an 'in-between' place inhabited by the subaltern” (91). For second-generation immigrants, the third space can operate as a space of difference celebrated by challenging "the notion of assimilation versus rejection which essentializes immigrants' experiences in terms of sameness, wholeness, and homogeneity (Pindi, 2018). As noted by Bardhan (2011), "working through the lenses of diaspora and hybridity can also help deconstruct old binary maps of cultural difference that follow the Us/Other negative logic of the West and the Rest" (45). Ultimately, such paradigmatic shifts allow creation for new ways of being by positioning identity as an unstable entity constantly performed "in-between" two or more worlds (Bardhan, 2012; Urban, 2008). For example, immigrants can use transnational space to perform difference as a way of interrupting sedimented/repetitive ways of doing and being in everyday life (Warren, 2008). Furthermore, Bhabha (2015) defines the "third space" as "cultural hybridity 
- committed to the practice of empowering minorities by envisioning forms of agency" (as cited in Pindi, 2018). Such celebration of difference is dialogically productive and useful "in the service of agentic and communicative identity building which can aid in healing identity trauma and (cultural) transformation angst experienced by young Tamil Canadian females in Toronto. Such an approach to difference evolves in the in-between space of two or more cultures/worldviews that valorize a conception of Self/Other as unique (Pindi, 2018; Bardhan, 2012; Godiwala, 2007).

\subsection{Acculturation, Multiculturalism and the Dialogical Self}

The model of acculturation has been embraced by several authors (Weichold, 2010; Salant \& Lauderdale, 2003; Kuo, 2014; Kessler \& Milligan, 2017). Acculturation strategies refer to the plan or the method that individuals use in responding to new, stress-inducing cultural contexts. A four-fold classification is proposed that includes "assimilation," "integration," "separation" and "marginalization." Berry and Sam (1997) suggest that the assimilation strategy occurs when the individual decides not to maintain his or her cultural identity by seeking contact in his or her daily interaction with the dominant group. When the individuals from the nondominant group "place a value on holding on to their original culture" (Berry \& Sam, 1997) and seek no contact with the dominant group, then they are pursuing a separation strategy. When individuals express an interest in maintaining strong ties in their everyday life both with their ethnic group and with the dominant group, the integration strategy is defined. The fourth strategy discussed in the literature is marginalization, in which individuals lose cultural and psychological contact with both their traditional culture and the larger society, and consequently experience a negative response from their familial/diaspora relationships (Berry \& Sam, 1997).

It is important to think of acculturation of young Tamil Canadian women as essentially a contested, dynamic, and dialogical process. Literature demonstrates that such a dialogical process involves a constant moving back and forth between various cultural voices that are connected to various sociocultural contexts and are shaped by issues of race, sexuality, and gender. 
In the last decade, scholars and researchers in psychology and related disciplines have explored the development of self as dialogical. For example, Bhatia \& Ram (2004) discuss culture, self and the stress of acculturation within the context of cross-cultural psychology. The dialogical self proposes a far-reaching decentralization of both the concept of self and the concept of culture - "cultures and selves are seen as moving and mixing and as increasingly sensitive to travel and trans-locality" (Hermans, 2001). Moreover, the self can either exist in alignment with culture, and/or detach itself from culture and mix with other cultures (Hermans, 2001). The self is not bound to one culture only but can move and exist in more than one culture at the same time.

Today, multiculturalism is embedded and operationalized in schools, law and other Canadian institutions (Amarasingam, 2016; Basu 2011). Few scholars have examined how immigrant, including refugee, newcomers have taken up this concept of multiculturalism and made it their own (or rejected it). One exception is a study of Sri Lankan Tamils in the Greater Toronto Area, that examined how members of this group view the relationship between their Canadian and Tamil identities in the context of multiculturalism (Amarasingam, 2016). Drawing on interviews and focus groups with both immigrants (first generation) and Sri Lankan Tamils born in Canada, his study unpacks meanings of multiculturalism among Tamil immigrants and their children (most of whom are now Canadians). (Amarasingam et al., 2016).

Several scholars, for example Razack (1998) and Thobani (2007), have argued that multiculturalism is an extension of the 'white settler state' which "allows just enough room to be different and accepted by Canadian society, but not enough to change institutional power or challenge patterns of privilege that stem from the settler state and its "whiteness". There has been little research, with first-generation Tamil immigrants and their second-generation children born in Canada about how they articulate their identities in Canada and "live" multiculturalism (or not) in their everyday lives, particularly from a gendered perspective. Many scholars have noted that while multiculturalism in Canada may be popular, it is also superficial: "a multicultural ethos rarely moving beyond 'saris, samosas, and steel bands' into something more substantial (Amarasingam, 2016; Donald \& Rattansi 1992). Amarasingam's research suggests, while first generation Tamil immigrants rejected multiculturalism (as an extension of the "white 
settler state') multiculturalism is real and woven into the daily lives of both Sri Lankan Tamil immigrants and second-generation children born in Canada. 'Multiculturalism', in this case, gets translated into daily routines of school, work, and community activities where children of Tamil immigrants begin to form an identity through, beginning the process of separating themselves from Tamil practices/routines.

Scholars like Amarasingam (2015) and Kernerman (2005) have dismissively described Tamil Canadians as "unable to articulate the multiculturalism that they live", and have concluded that multiculturalism, as an ascribed principal, does not have enough substance to fully unify them into Canadian society because they will always be seen as visible minorities (Amarasingam 2015; Kernerman, 2005). When asked what it meant to be Canadian, several second-generation Tamil youths demonstrated the dialogical self - the ability to engage two different cultures; referencing themselves as multicultural (Amarsingam, 2016). First-generation Tamil immigrants/parents contended that multiculturalism functions as a kind of "Canadian nationalism" (Amarasingam, 2016), which is why they felt their children were neglecting their Tamil culture by assimilating to Canadian culture (i.e. speaking English inside the household, rejecting ethnic cuisine, choosing to hang out with friends who were not part of the same religious/ethnic background). Despite the varied and valid criticisms of multiculturalism as a policy, Amarasingam's study takes a step back and asks a different question: is multiculturalism enacted among Canadians who are part of a racialized diaspora and for whom Canada was a country of Asylum?" (Amarasingam, 2016). There has been little research, with first-generation Tamil immigrants and their second-generation children born in Canada about how they articulate their identities in Canada and "live" multiculturalism (or not) in their everyday lives, particularly from a gendered perspective.

\subsection{Roots of the "Good" Tamil Daughter}

In Tamil society, the birth of a female child is often seen as a burden rather than the blessing of a male child (IAWID 1995). Scholars like Chatterejee (1989) have looked at the construction of the traditional Tamil woman as "fertile nurturer, chaste woman, spiritual and dutiful housewife" (Chatterjee 1989). Thirinigama (2001) and De Mel (1998) who have also looked at the women in the Tamil [Canadian] diaspora, often link their role as nurturers to their 
eventual role as martyrs "willing to sacrifice themselves for the greater good of their family status/reputation" (Gowrinathan, 2012). Some of the key aspects underlying the construction of the "traditional" Tamil woman are the space they occupy, acceptable codes of behavior, the significance of marriage/dowry, and the symbolic values associated with them.

Gender roles in Tamil diaspora(s) are rooted in a more generally observed trend of clear divisions between public and private space for women in South Asia. These divisions have been understood at a theoretical level by scholars who look at the distinction between the two spaces "public space becomes largely a political domain, and women, primarily operate in the private space of the home (becoming 'politically invisible"' (Gowrinathan, 2012). Looking at Sri Lanka in particular, Chatterjee finds that "The way gender operates in society, the public is typically the domain of the male, and at the home or inner space, which 'must remain unaffected by the profane activities of the material world' is represented by women" (239). This division between public and private space in society is often one of the first, most visible, indications of gender relations within any society (Gowrinathan, 2012). During the Civil War in Sri Lanka (1980's) the public space became more heavily militarized with increased army presence; ergo, the physical absence of women/daughters in the public streets became invisible. Commenting on a similar phenomenon, Thiranagama finds that the private/public divide in Tamil society also allowed for a "repression in [the] private life [of Tamil immigrant daughters]" (330).

The space we [Tamil daughters] occupy, translates into and explains the expected codes of behavior for women. "Women were expected to dress conservatively (with long skirts, hair tied, small gold earrings), behave in a demure manner, and never draw attention to themselves" (Gowrinathan, 2012). In a rare interview, then leader of the Liberation Tigers of Tamil Eelam (LTTE) Women's Unit, Thamilini, described the position of young Tamil women:

'Our girls grow up being tied down. 'Don't smile.' 'Put your head down.' 'Walk gently.' All these are unwritten codes of conduct. If any woman were to act differently; it is viewed as though the whole world has collapsed on our shoulders." (Sinnathurai 2005).

The socialization of gender roles, and the distinction between young men and young women, starts at a young age, when girls and women often learn to put themselves second, and the men around them, their family, and community honor first (Rajanisingham-Senanayake 2001). These codes of behavior were later drawn on and formalized in Tamil diasporas in 
Westernized countries like Canada, which laid out what it meant to be a "Tamil" woman, and the responsibility of women to protect that identity. (Schalk 1994).

Satkunam (2016) examines how women are seen as biological reproducers of members of ethnic collectivises; as participating centrally in the ideological reproduction of the collectivity and as transmitters of its culture. Women are perceived as taking on the duty of reproducing cultural identity. In this way, the burden of remaining culturally pure can fall heavily on a woman, as she is expected to teach the future generation how to behave. As a result, everything a woman chooses to do can be scrutinized by their community, which can especially frustrate second-generation women, who may want to assimilate, but are expected to uphold values from their homeland.

Mehrotra (2016) speaks about South Asian women and marriage, and how a number of authors have assumed the importance of gender, marriage, and family within South Asian diasporic culture without hearing from South Asian women directly with respect to their own lived experiences and perspectives. Through interviews with South Asian women living in the U.S., Mehrota shows that across generations, messages about (heterosexual) marriage emerged as central to how women understood their gendered experience and, as such, marriage and being marriageable function as a "cultural script" for middle-class South Asian womanhood (Mehrota, 2016). Women's narratives from her study elucidate some of the specific messages of this "cultural script", and everyday ways this script is indirectly and directly communicated to women within family and community interactions (Mehrota, 2016). Although this study takes place in the U.S. and generalizes South Asian women into one subject, this example is very parallel to the Sri Lankan Tamil mentality of marriage and is one of the most oppressive "scripts" Tamil daughters are to adhere to. Aforementioned, while the importance of gender and family in South Asian culture has often been assumed within scholarship and communities alike, little research has been done to understand South Asian women's lived experiences from their own perspectives or across generations (Mehrota, 2016), thus justifying the need for an autoethnographic approach. Much of this literature remains conceptual or based in macro-level analysis. Being competent in traditional household tasks such as cleaning and cooking was part of many women's gender socialization to varying degrees Similar observations have been made about immigrant women from other ethno-cultural contexts including a study of Filipina- 
Norwegian immigrants' stress/distress from the impact of their role as a daughter/wife, and the associated expectation to marry (Straiton et al., 2017). However, the normative role as the "dutiful daughter or altruistic mother" means that women would sacrifice their own needs in order to marry Filipino men residing in the Philippines and send remittances back home (Straiton et al., 2017). Filipina daughters took on multiple jobs to the point of exhaustion, engaged in studying in order to improve future earnings, forwent trips home to visit family and even delayed motherhood. By putting the family's needs before her own, she fulfils the role as a virtuous and moral daughter or sister. Many South Asian immigrant women from Mehrota's study (middle class, Indian, raised Hindu, highly educated, able-bodied, documented, English-fluent, and heterosexual) talked about how domesticity was highly valued as part of being marriageable and becoming a daughter-in-law. "When asked about what she learned growing up about being a South Asian woman, she recounts the importance of being trained to be a daughter in law" (Mehrota, 2016). Enforcing the relationship between the cultural script, gender, and one's place in the kinship structure is important to note here since little research has been done to understand South Asian women's lived experiences from their own perspectives or across generations.

\subsubsection{Tamil Daughters as Carriers of Culture}

Within the field of Tamil Canadian and South Asian gender studies, Amarasingam (2008), Ferrari et al (2013), and Tyyskä (2015), have focused on the diasporic experiences of Tamil Canadian youth in relation to religion and language challenges, yet they do not focus on the peculiarities of Tamil daughters and the practices they are raised to obey without choice. These scholars point out that many youth are losing their proficiency in the Tamil language despite being an essential component of their ethnic identity. The research, although preliminary, begins to fill gaps in scholarship on the Sri Lankan Tamil population in Canada, as well as the role of religion, and language barriers in the lives of immigrant youth in Ontario (Amarasingam, 2008). In the literature, limited attention has been given to the difference of cultural preservation Tamil female youth are responsible for vs. their male counterparts. While studies have explored how Tamil youth are expected to sustain ethnicity through seemingly mundane acts such as wearing a sari to a family gathering, eating with their hands, and watching Tamil movies (Amarasingam, 2008), they do not explicitly examine how daughters are disproportionately 
responsible for passing on their cultural heritage to their future children, and related impacts or implications.

This study also builds upon the key concept of women as carriers of culture (Satkunam, 2016). As a result of the violence and colonial influences diaspora members faced, they may hold onto their cultural identity as a means to overcome trauma. The above discussion on the dialogical self in culture, builds upon cultural identity as an idea of a shared or a collective 'one true self'. To answer why young Tamil Canadian female find it difficult to negotiate their identity, it is because this idea of cultural identity is contingent on their parents' past. Hence, there's a tension between considering culture as static and changeless (Satkunam, 2016). Central to Satkunam's discussions are the issues of cultural retention, the diasporic experience, hybridization, and cultural authenticity. To put it simply, there has been much angst around what it means to be Tamil in a place far away from "home". This quest, the longing for and reinvention of home takes place within the context of assimilationism: immigrant parents anxiously watch their daughters in an effort to gauge what aspects of anglo Canadian culture will be adopted (Handa, 2003). It is feared that if not guided properly, daughters, the inheritors and future transmitters of cultural practices and artifacts, could forfeit their authentic, ethnic identity, or worse still, fall prey to the "ills of a modern Western society" (Handa, 2003). In Canada, Tamil identity is based on certain acts of "cultural preservation". Cultural preservation is using certain cultural markers, based on customs, gender, and historical contexts, to assert boundaries, or to set apart, a minority group in a country (Handa, 2003). Cultural preservation becomes a key means to preserve a diaspora identity, and to ensure cultural norms exist within a new country. A women's sexuality in society can be highly controlled, as it is seen as a key factor in nation building.

Gowrinathan's work examining gender roles among Tamil youth, surmised that understandings of gender roles were reflected in participants' interactions with each other (41). Her analysis included examining youths' understanding of the gender distinction between private and public spaces, as they manifested themselves in Tamil society (Gowrinathan, 2012). When discussing the activities appropriate for women within the home, both Tamil boys and girls (participants) answered that they should "wash pots and pans, sweep, cook, serve food, wash clothes, and take care of the parents" (43). Within the home boys felt that men should be 
responsible for shopping and gardening, while outside the home their options were limitless. "Men should do everything since they are able to, they should help women since they can't do everything." (43) Men, they felt, were more suited for salaried work while women more suited

for work in the home. "If they were to work outside the home, they could be a teacher, nurse... Girls, they felt, should do only 'what is suitable for girls' (43). The general consensus was that for those occupations that were suitable for both men and women, men should be paid more because they will work harder.

As Gowrinathan explains the young women in her study felt that while men could do anything, outside the home women could be a "doctor, teacher, scientist, judge, scientist, astronaut or clerk" (44). They felt strongly, however, that where men and women performed the same work, they should receive the same recognition by society and their migrant family members. When Tamil youth were asked whether they felt husbands and wives were equal, the male participants overwhelmingly felt that they were, while the girls were quick to point out obvious inequalities. "If men can go out at night, and women can't then how can they be equal?"(45).

The more complex understandings of the private/public spaces women and men occupied were not necessarily part of the children's understanding of gender roles within the private space of the home, however the underlying assumptions (that women should be married, and must take the role of mother seriously) did have relevance in the daily lives of the children involved in this study and were cultural norms that they both prioritized and didn't question.

\section{CHAPTER THREE}

\section{Methodology}

\subsection{Research Approach}

My epistemological approach is through the qualitative method of autoethnography. Creswell (2014) defines autoethnography as "a reflective self-examination by an individual set within his or her cultural context." I have chosen autoethnography to explain and describe my cultural hybridity, identity, traditions and lived experiences performed across two cultures, at the 
intersection of various facets of my selfhood: Brown, Sri Lankan, diasporic, Tamil Canadian, female, daughter, second generation immigrant, English Speaker, flawed Tamil Speaker, and so on. I will examine how my own lived experiences and interactions with other Tamil daughters compare and contrast with existing theoretical/explanatory concepts in the literature (e.g. hybridity-third space, acculturation and the good daughter).

Autoethnography is an important narrative strategy for reframing critical moments of the selfhood. As an emerging researcher in the field of leisure studies, Pavlidis (2013) makes a case for autoethnographic writing in feminist research, and argues it as a valuable methodological approach for feminist analyses as it enables researchers to explore new questions, and identify ways to theorise the complexity of gender power relations as they are embodied in culture. To the question "what is autoethnography?" Ellis (2004) responds, "research, writing, story, and method that connect the autobiographical and personal to the cultural, social and political". Rather than view academic writing as a "science" (Pavlidis, 2013), I have understood it to be a platform for creatively expressing my voice. Markula (2003) wrote, "If we think of our lives as works of art, we regain the ability to think creatively and challenge the limitations of the 'natural' identities formed through the games of truth". In moving away from assumptions about gender and subjectivity that are deemed "natural", limits are opened up and new questions can be asked. Therefore, through my own narratives, I hope to reclaim agency for Tamil Canadian daughters and educate our diaspora away from assumed gender roles/expectations.

According to Roth (2005) critical inquiry like autoethnography is essential for generating new scientific knowledge because "we can overcome the epistemological problems raised by the observer/observed and mind-body dichotomies by drawing on first-person methodologies', Similarly, Taylor \& Coia (2009) highlight the usefulness of autoethnography as a method of teaching praxis, particularly through the use of storytelling. Wake (2018) uses this as a tool in her critical vignette writing, for reconnecting herself, the researcher, to her overarching research question. As Taylor \& Coia (2009) explain, autoethnography is " a method that prioritizes the stories of researchers as a way of making sense or theorizing about their study" (4). An autoethnographic approach will enhance the discourse surrounding my research question because it will allow the participant - myself, and those around me - the reader, and broader society in 
which we live in, to learn how second-generation Tamil Canadian women experience trauma when negotiating their identities.

Autoethnography provides the ability to demonstrate "reflexivity" through self-reflection of my lived experiences as a cultural hybrid. Reflexivity is referred to by Adams et., al (2015) as a process that enables the subject to acknowledge and investigate their connection as an individual within society, or the phenomenon in which they choose to explore. Belonging is a key theme in immigration and feminist research (Gibson et al, 2012; Glover \& Parry, 2008), yet the experiences and voices of myself and others who have "not belonged" have been marginal in these studies. Through the use of personal narrative, my writing opposes singularity and positivist assumption of a singular truth (Rinehart, 2005), and in doing so moves away from debates about agency and structure to think differently about academic writing, resistance and empowerment in immigrant-feminist research.

\subsection{Vignette Writing}

Autoethnographies are often communicated through storytelling. According to Emilie Cameron (2012), "'Stories express something irreducibly particular and personal, and yet they can be received as expressions of broader social and political context, and their telling can move, affect, and produce collectivities". Storytelling is an example of "creative analytic practice (CAP), an arts-based method that positions the writing process as a focus of inquiry, and as a key to representing and fostering appreciation and acceptance of the perspectives of others" (Edge, et al, forthcoming). Growing analyses on CAP suggest that this writing style shifts away from the 'traditional' and 'static', rather 'uncreative' modes of presenting qualitative research findings (Edge, et al, forthcoming, 6). CAP creates room for the writer to subjectively and reflexively represent personal and social meanings, and experiences (Edge, et al, forthcoming; Richardson, 1997; 2007).

One popular method used by CAP researchers is the vignette. Creative vignettes or shortstories are an inclusive method of communication as it allows both traditional and non-traditional research audiences to engage with the material, relate to the research analyses, draw their own conclusions, connect with the feelings and emotions of the researcher/participants and retain 
information in ways that traditional representations of research findings sometimes do not (Edge, et al, forthcoming). Researchers have the freedom to create their vignettes in whichever way enhances the quality of their overall study, since vignettes range from completely factual representations (e.g., Wake (2018) to completely fictionalized or authored representations (e.g., Williams (2013) (Edge, et al, forthcoming). There are also hybrid approaches which create fictionalized vignettes or scenarios that are rooted in reality or empirical observations (Edge et al, forthcoming).

I adopt a hybrid approach through reliving conversations with my sister and parents relating to time frames, events and phenomena. In explaining her process Wake (2018) describes how looking at family photos was a very powerful medium which evoked emotional and sensory memories (both good and bad). Once the emotional and/or sensory response was triggered, she would journal and craft each entry into a personal thought. Mentioned in her study is the technique of listening to old audio from video recordings. In this study I also listened to recordings with my parents, family members, cousins, Tamil church members, as a means of bringing about mixed emotions, memories and philosophical conversations in my own head, that then inspired a series of hypothetical vignettes that were rooted in truth, yet also constructed. For example, I do not include any direct quotes or thoughts shared by other members of my family or members of the community within my vignettes. Any conversation depicted is purely hypothetical and intended to help illustrate my own perceived experience.

In an attempt to communicate how culturally hybrid expectations disrupted significant stages of life, Wake (2018) adopts Erik Erikson's Theory of Psychosocial Development with emphasis on the 5th Stage 'Identity vs Role Confusion' to examine experiences between the years of twelve and eighteen (see Appendix A). She documented noteworthy events that she believed were pivotal links between her cultural hybridity and sense of identity. Wake claims she is one of the first to apply this theory of psychosocial development to women. By reproducing this method, I too have the opportunity to highlight disruption caused by cultural expectations, in significant stages of life. In Table 1 of the findings section, I document noteworthy events that I believe were pivotal links between my cultural hybridity and sense of identity. This helps to provide important context to the series of illustrative autoethnographic vignettes that follow. 
Another example of vignette writing within the context of immigrant studies is Williams' (2013) work on the well-being of Kenyan-Canadian parents and youth living in mixed families in Montreal. Williams crafts fictionalized vignettes - Ndio na cheka: That's why I laugh, and My child is going to learn both cultures. Her study adopted a qualitative research design, with a small sample size of Kenyan-Canadian participants who shared their understandings of their experiences in Montreal. She conducted open-ended interviews with Kenyan-Canadian mothers and daughters. Based on the conversations sparked in the interviews, Williams found inspiration for her fictionalized vignettes. Interviews were conducted in English, Kiswahili, and Sheng and were later translated verbatim (Williams, 2013). However, critical concepts or terms in Sheng and Kiswahili were not translated, so that their translation could become the subject of her vignette (e.g. My child is going to learn both cultures) (Williams, 2013; Green \& Thorogood, 2009).

Kress \& Lake (2018) attempt to provide greater detail on how they go about orienting themselves into a story so that it is communicated in a way that serves reflexive purposes. In their opinion, authors should first orient themselves from vantage points that on the surface appear vastly unrelated so that: "within our different perspectives, we can also see moments of convergence as particular themes touch our lives. Perhaps most loudly in these examples, we hear resonance at the nexus of 'place' and identity" (Kress \& Lake, 2018). These authors suggest that at the beginning of the creative and analytical process, impactful written narratives appear slightly unrelated to one another, yet through each different perspective that is subsequently relayed a pattern of themes that connect each narrative to the core focus of the research question becomes more apparent.

Pindi (2018) narrates an autoethnographic journey of the self across the Congolese and American cultures through the construction of personal narratives that depict self-talk and internal thoughts to communicate her process of identity construction. Though Pindi (2018) does not explain her process of gathering and recording her personal narratives, Taylor \& Coia (2009) point towards some strategies: writing/saving drafts on google docs, gathering data by sharing written narratives and reflections with family and friends in your community, and audiorecording self-thoughts/reflections so that it is easier to record thoughts that might have happened earlier on in the day. Taylor and Coia's (2009) methodologies included the 
aforementioned - gathered copies of written narratives and reflections on the process (shared with between each researcher via emails), transcribed audio-tapes of the sharing sessions, printed email exchanges, drafts of collaborative writing on google docs, and field notes from their phone call discussions. I will use the following methods in my approach: writing/saving my drafts on google docs, share my reflections with my family/friends in my community (particularly my older sister) for feedback, and audio-record self-thoughts/reflections that it is easier to revisit these thoughts as I write on them. In communicating their autoethnographic studies, Wake and Pindi also take the approach of exercising self-awareness or reflexivity through self-talk(s) and personal thoughts. I will adopt a similar approach and use my personal narratives to recount critical moments of my lived experiences as a hybrid subject navigating at the borderlands of two cultural worldviews: Tamil and Canadian.

\subsection{Approach to Vignette Construction}

Can we really capture a moment in writing - be it unspoken, spoken, or filled with only an emotional cry? At the heart of things is chaos and it lived in my unconscious, where I learned to open it and raid the inarticulate. At the crossroads of my lived experiences and the opportunity to explore the psychosocial development of my cultural self through a Master's program on Immigration and Settlement Studies, I have decided to articulate the rumblings from the uncoded voices in my head, translate them into creative narratives, and contextualize related insights within the context of existing academic literature. As the writer, I was very open to hearing those rumblings when they arrived, even if I was occupied with something else. My approach to all of the vignettes was to write about bliss, about an upsetting moment, about my father, about the dinner table growing up. In my vignette section, I capture both large and small moments - to capture the common humanity and claim of agency of Tamil Canadian daughters of immigrants. I write from my own perspective, and I interpret what other's may say/think in italics. I adopt Kress and Lake's (2018) attempt in orienting myself into a story so that it is communicated in a way that serves reflexive purposes. I provide subheadings to each story so that the reader can see when theoretical concepts of hybridity, acculturation, and the third space are being explored within the context of my lived experience and core themes throughout my life. In each vignette the reader will experience the nexus of 'place' and identity" that exists in my life (Kress \& Lake, 2018). My written narratives may appear slightly unrelated to one another, yet through each 
subsequent vignette or account, there arises a common pattern of themes that connect each individual vignette to the core focus of the research question (Kress and Lake, 2018). I have taken creative liberty throughout to illustrate my own emotions that colour these factual events that have taken place in my life.

\section{CHAPTER FOUR}

\section{Results}

\subsection{Psychosocial and Maturation Milestones of Angeline Sahayanathan}

Following Wake (2018), who adopted Erik Erikson's framework on psychosocial developmental stages, I utilized a comparative table of psychosocial and maturation milestones to help my young adult self to understand the complexities of my lived experiences. Erikson's theory has been discussed in relation to being specific to the male gender (Wake, 2018), however, I apply a feminist standpoint to demonstrate and explain significant personal lived experiences. In Table 2 below, I document noteworthy events that I believed were pivotal links between my cultural hybridity and sense of identity. The reference to developmental milestones within my discussion of hybridity and identity relates primarily to defined stages of life development where specific proficiencies in relation to age are met. There are many theorists who espouse the importance of meeting an accepted progression of developmental stages during childhood until adult maturation. Erikson is one who is most commonly referred to for guidance (Wake, 2018). Their principles and theories uphold the view that, for successful transition into adulthood, understanding psychosocial disorder is essential, as it has a direct impact on the developmental processes (Wake, 2018; Remschmidt, 1994). 
Table 1. Psychosocial and Maturation Milestones of Angeline Sahayanathan

\begin{tabular}{|c|c|c|c|}
\hline $\begin{array}{l}\text { Erikson's 5th Stage } \\
\text { Identity vs. Role Confusion }\end{array}$ & Expected Achievement & $\begin{array}{l}\text { Disruption } \\
\text { Attempted and Thwarted }\end{array}$ & Actual Achievement Reality \\
\hline $\begin{array}{l}\text { Contemplating future in terms } \\
\text { of career, relationships and } \\
\text { family }\end{array}$ & $\begin{array}{l}\text { Independence/Adulthood, } \\
\text { Career }\end{array}$ & $\begin{array}{l}\text { 1. Female gender within the } \\
\text { family has a determined } \\
\text { future as wife and mother. } \\
\text { Independence not achieved } \\
\text { - heavily influenced by } \\
\text { parents and older sister } \\
\text { 2. Decisions related to career } \\
\text { and relations is subject to } \\
\text { permission from parents, } \\
\text { not independent } \\
\text { Education and career goals } \\
\text { receive very little support } \\
\text { from parents unless decision } \\
\text { to be a doctor, lawyer, } \\
\text { engineer }\end{array}$ & $\begin{array}{l}\text { 1. Adulthood not realized, thrust } \\
\text { into role as "independent" } \\
\text { when going into university and } \\
\text { professional work place } \\
\text { 2. } \begin{array}{l}\text { Transition from financial } \\
\text { dependence on parents, to }\end{array} \\
\text { independence at the age of } 22 \\
\text { 3. } \begin{array}{l}\text { Earned sole decision-making } \\
\text { over my career at the age of } 22 \\
\text { - earned my parents' trust and } \\
\text { respect }\end{array}\end{array}$ \\
\hline
\end{tabular}


The table above breaks down the maturation stages of my life in which my hybridity and identity struggled to thrive amidst intense cultural and religious expectations. Common themes that occur in this table are in accordance to Erikson's theory of psychosocial and maturation milestones - independence, transition into adulthood, and exploration of identity. In accordance to being a daughter to very religious and highly respected members of the Tamil diaspora, the table reflects how my future has been decided for me, decisions related to my career require the approval of my parents, and social networks were very much under the monitorization of my parents. Culture plays a role in my discipline/behaviour construction (e.g. not allowed to dress certain ways, due to a strict moral and religious family) and lack of independence (e.g. adulthood not realized, thrust into role as "independent" when going into university and professional workplace).

The reference to developmental milestones within this table, relates primarily to defined stages of life development when specific proficiencies in relation to age are met. Erikson provided me with the groundwork to examine my developmental milestones from early childhood until adulthood. His principles and respective theories uphold the view that achievement for successful transition into adulthood benefits from the understanding that psychosocial disorder has a direct impact on developmental processes to adult maturation (Wake, 2018; Remschmidt, 1994). Vygotksy's theory of cultural history advances this view, claiming that one must understand that until you take account of a child's culture and biological influences which are related to their cultural foundations of beliefs and values, then the stages of development cannot progress to adult maturation (Wake, 2018). Concurring with this theory, Fleer (2006) affirms that "culture not only determines the principles for defining development but frames the contexts in which the development of child is supported" (8). A significant emergence from my reflexive data was the realisation and implication that my psychosocial development was at odds with the Erik Erikson's fifth stage of human development theory, deeming my development to be chronologically disrupted and dysfunctional (see column Disruption Attempted and Thwarted) (Dunkel \& Harbke, 2017). The fifth stage of Erikson's theory reasons it as imperative that the individual achieves this stage between the ages of 12 to 18 as it builds on identity formation and gives a sense of self continuity within their life (Dunkel $\&$ Harbke, 2017). However, in my life, it is evident that identify formation was only explored at 
the age of 18 , and is only being achieved now, at the age of 23 . Table 1 demonstrates the development of my life stages in thematic milestones, compared to Erikson's 5th stage of human development.

Self-authenticity within my autoethnography becomes an indomitable force guiding my vignettes to identify cultural and personal identity, psychoscocial development and cultural hybridity. The ability to overcome challenges/thwarts, such as being influenced by powerful others (i.e. my immigrant parents, my migrant community) and having a culturally constructed life, has enabled me to write my autoethnography.

\subsection{Introduction to Vignettes}

My work will feature vignettes about my life that highlight my personal journey and negotiation around cultural expectations. My experiences as a daughter of migrant parents who often dared to dream beyond her determined life is captured within the following stories of my lived perspective - the perspective of an interested, at times ambivalent, at times deeply passionate woman with a desire to think differently about the self, the Tamil Canadian woman, the rules and writing.

\subsubsection{Who are you?}

Who are you, characterises my inability to confront my personal identity within the space of cultural hybridity, and consequently my self-disappointment. This vignette is an illustration of my voice hearing itself for the first time in the third space. Who are you demonstrates the confusion and isolation I experience amidst acculturation, as I struggle to navigate and immerse myself into full "Tamilness" and fulfil the destiny mapped out for myself. This vignette admits I am a part of a third space that acknowledges my cultural hybridity, though I have not fully understood it yet.

I position myself as a cultural hybrid subject - someone who encompasses cultural practices and values from two different areas of the world. I identify as Tamil but act Canadian - and that doesn't have to make sense to you. I am a postcolonial subjectexisting after the cultural genocide Sinhalese officials committed against Tamil people. I 
am an English-speaking Canadian, and a hopeless non-native Tamil speaker trying to identify with the diaspora I was born and raised in.

Where did I go wrong? How could I not master my mother tongue like my brothers did? Why do I feel so different? Why don't I belong. Why do I always feel different no matter where I go?

I am indeed a transnational subject. I live in Toronto, Ontario - Scarborough, mini Jaffna is what I call it. I belong to here and there. Each of these identity layers is intertwined and impacts my lived experience in everyday life.

\subsubsection{He's Wrong}

He's Wrong draws upon Chatterjee (1989) and Thirinigama's (2001) analysis of the construction of the traditional Tamil woman. I was on the bus with a Tamil neighbour, who had a very strong opinion on the way Tamil girls should "carry themselves". As a second-generation Tamil male, I was shocked to hear his gendered assumptions align so acutely with those of my first-generation Tamil family/community members. I felt it was imperative to delineate his mentality, though it was difficult to re-live. This vignette looks at the way gender operates in Tamil culture - proving the public is typically the domain of the male, and the home or inner space, which "must remain unaffected by the profane activities of the material world" is represented by women (Chatterjee, 239). The Tamil diaspora in Toronto continues to link their daughters' role as nurturers to their eventual role as martyrs "willing to sacrifice themselves for the greater good of their family status/reputation" (Gowrinathan, 2012). If any daughter rejects this responsibility, she becomes a threat, to herself, to her future husband and his family.

He never really liked Tamil girls. He said that most of us are too dramatic, that we attract issues and fabricate friendships. We're too loud and try too hard to be 'white'. He told me that we get good grades and we're too focused on getting into the best university programs ... but we end up working in a bank ... or at a desk job. I asked him why he thinks that - and he told me this: If you notice, Tamil girls don't strive to be 'successful'. They can't handle a demanding job because they're taught that they have to raise a family, take care of the husband and kids. Do you really think a Tamil girl will choose a job over her life? Do you really think they can handle anything beyond a simple 9-5 job? How do you expect her to explain that to her parents and her husband's family - that she wants to be CEO. They won't 
want that. Also, if she's successful, men won't want her. Tamil parents already know, if they raise their daughter to be successful, finding her a husband will be hard - no one wants a woman who outshines their son.

- 7 a.m. morning commute conversations with a Tamil male stranger

\subsubsection{Days and 40 Nights}

40 Days and 40 Nights reveals my position as a Tamil daughter interspersed with confusion of what roles I have to assume/meet on a daily basis. This vignette assists the examination of life stages. The achievement of successful transition into adulthood espoused by Remschmidt (1994) has a direct impact on developmental processes if psychosocial disorder is avoided. An equally significant aspect has Fleer (2006) claiming that "culture not only determines the principles for defining development but frames the contexts in which the development of child is supported" (8). It was imperative that I demonstrate the conversations my father and I share, as I reflect on the impacts of rejecting cultural practices/expectations upon my mental well-being, and relationship with him. In reference to Erikson's fifth stage of psychosocial development (see Table 2) my life was constructed within a dominant culture with no opportunity to experience self-authenticity as part of my identity formation. As a consequence of being totally dependent on "powerful others and having a culturally constructed life" (Wake, 2018), my vignette takes up the courage to express the pain my authentic self has endured. The non-existence of a bicultural relationship between my family and the Tamil way of life added to my continual frustration and shame. My frustration - was born out of the sense of having zero control over my identity negotiation, which manifested along a continuum of constant resistance to acknowledging that I was expected to follow all practices handed to me with no say at all.

My dad's coming back tomorrow - I hoped. I was used to this - my dad used to travel a lot when I was a kid, and I never used to feel anything. But this time it was different - I was cold all the time, felt isolated and alone.

My dad bugs me and Akka all the time about cleaning, washing the dishes, sweeping the kitchen, preparing the food. “வீட்டை சுத்தமாக வைத்திருப்பது பெண்கள் பொறுப்பாகும்" [girls are in charge of keeping the house clean] he says. Usually I brush 
it off, but one day I couldn't take it anymore. I told my dad so many times that he needs to stop making me feel like I'm only a good daughter if I follow those rules. I can't even begin to tell you how many conversations I've been a part of, where my parents and uncle and aunts all complain about us girls. My dad is the only male in the house which makes it even harder to detach ourselves from such expectations. He needs something to boast about us, and somehow my house chores outweigh my strong education.

Over the last 5 years I've tried helping my dad unlearn culturally associated gender roles hoping he'd progress and become less patriarchal. Some days are more successful than others. One day in particular was less successful than others. I remember Appa was putting away the salsa bottle because Akka didn't close it properly. He got really mad (because she also stayed home all day and didn't clean the kitchen). He started yelling at her and said, "this is why there needs to be a man in the household - sometimes you girls don't know how to do things". Akka got defensive and she yelled back saying something was wrong with the can and she couldn't close it. Appa got triggered and he said, "that's because you aren't strong - leave the strength stuff to me." I remember feeling my gut drop into the pit of my stomach when he said that. Did he just say that? That's the thing I don't understand - as a father to daughters, don't you want to address them as strong women? Don't you want to acknowledge them as intelligent people?

The conversation escalated and I argued back and forth with Appa asking him how he could speak to us like that. I was angry he kept calling us weak and disobedient because we weren't following his expectations. I was angry at everyone for placing me and Akka in that narrative. I was angry at everyone who ever spoke down to my Tamil sisters. They can't just sit there tearing us down just because we don't clean the house every day it's just not fair! How can they look at us and say we're weak? We work so hard every day, so we don't bring shame to their name. Every day I wake up to my mom asking me to change my outfit from shorts to pants, from tank top to turtle neck, "your top has to be below your hips". I at least change three times before it's acceptable to go outside “அந்த உடையில் உங்களைப் பார்க்கும்போது மக்கள் என்ன நினைப்பார்கள்? உங்கள் குடும்பத்தின் நற்பெயரைப் பாதுகாக்கவும். உங்கள் பெயரை அழிப்பதைக் காண 
நாங்கள் இந்த நாட்டிற்கு வரவில்லை [what will people think when they see you in that dress? Protect our family's reputation. We didn't come to this country to see you ruin your name].

Every time I try to stand up for myself, or my sister, they always guilt-trip me into thinking I've taken advantage of them - taken their disciplining for granted. For some reason, when I claim that I am more than a housewife, it makes them feel like they've failed to raise a good daughter. Appa always cries and then yells saying something like, do you know how hard me and Amma work? What do you girls do? We go to school every day, study hard to get the grades that are acceptable for them, and then we go to work, to earn money and help around the house. Studying isn't easy, and sometimes I want to yell out “you wouldn't know because you never got an education! What do you and Amma do that's so significant? How would you like it if I said 'oh, what do you and Amma do? You just sit on a desk all day until it's time for you to come back home."

It's the sad truth isn't it? Our parents come back home and tell us how we're not good enough - all because "we don't take care of the house", or we still haven't learned how to cook, or that we came home a little later than curfew. Is that all they care for? It doesn't matter what degree or job we get - all I'm good for is how well I cook and clean.

You talk too much - my dad tells me, as tears are rolling from my face from frustration and feeling like I'm being suffocated. When I stand up for myself, he asks me, do you think you're smarter and better than everyone here. Do you know how much I do for you? You make mistakes and I take everything upon me. When people judge what you're wearing, see you with a boy in the mall, look at your Instagram picture - they call me and say what is your daughter doing? Watch her. And I take all the blame just so no one says anything bad about you.

Okay I'm sorr- ... I just don't understand why they have to connect our capabilities to tasks like that - if all you expect from me is to sit at home and clean then FINE. I'll quit school. I'll quit trying. What's the point?! You're talking nonsense, Appa will say to me. I'm spiraling. But I can't stop crying. I'm so hurt. I feel like I can't breathe, and I don't feel like 
I'll ever be good enough. My parents are embarrassed by me because I'm not the kind of daughter they hoped for. I'm a disappointment.

For some strange reason, she has something against me. I was nothing but a good father, but she hates me! She wants to hurt me. Tell me what I ever did to you! You always think I'm against you, always think I'm trying to hurt you. I'm a bad father it seems.

I respond: You're not Appa. It's just - ever since I was little, you always seem disappointed in everything I or Acca do. You never seem happy with us. You always look at me with remembrance of all the rules I've broken. I'm trying to be a good daughter, but you seem like you don't want to understand who I really am. There's more to me, don't you want to know who she is? Don't you want to celebrate her?

Silence. He didn't respond. One day later, silence. Two days later, silence. Three days later, silence. Silence continued between us for forty days and forty nights.

\subsubsection{Discovering the Third Space and the Cultural "Other"}

Discovering the Third Space and the Cultural "Other" relates the initial impact of my cultural identity, blended with my experiences as a Tamil daughter who did not fit in for numerous reasons (e.g. appearance,, nationality), whilst adhering to a strict familial life as a daughter within a culture where female gender is governed. I was not aware during this period of my life that cultural hybridity was embedded into my identity and this becomes evident when I describe the questioning I receive for calling myself Canadian. Through this story, I claim agency for Tamil daughters who also experience this awakening - discovering her third place and being seen as an "other".

My older sister and I were born in Canada. We were fortunate enough to have family members who were part of an established Tamil diaspora here in Toronto. This meant access to a better life and opportunities that so many other Tamil children were denied as a result of the ethnic conflict that ravaged Sri Lanka for decades. 
Being raised in a close-knit Tamil community was bittersweet. On one side, I always felt like I had tons of brothers and sisters, always ate good food, celebrated a lot of festivities, etc.; but it also exposed me to a lot of internal pressure. So many people expect a lot from us girls, more than our male counterparts. They never asked the boys "where were you last night why didn't you answer your phone?” or, “how can you think about moving away for university? Go to UTSC and stay close to home."

Nonetheless, I still remember the amazement of life in Scarborough. The most interesting thing to me was the people. I was able to interact with kids who looked so different from one another - I loved having friends who were Black, White, Asian, Hispanic. As a child it felt like a wonder to have people from around the world come together in one place and become friends with them. This fascination with the diversity of our community has never left me. Sometimes my family members would get upset if I wanted to play with my non-Tamil friends and I could never understand why. They made it seem like I was betraying them.

As I grew older, I began to question my individual identity and sense of belonging as a second generation Canadian. Being a member of a visible minority community, there are instances when I feel insecure about my Canadian identity. Like when I'm decked out in red and white, with our flag proudly flying behind me as a cape, and still having to repeatedly answer the question, "But where are you really from?" There was this one time a classmate of mine ignorantly asked me if I was a Tamil Tiger after reading mainstream media reports about the height of the war in Sri Lanka. While they may be minor passing remarks, the accumulation of these types of experiences can cause you to ask: What is my identity in this country?

For me, it's that I'm a Canadian with a Tamil heritage, something I've been able to explore through my upbringing. Race remains a prominent component of my hybrid identity in Toronto. My ethnic identity as "Tamil" and my nationality as "Canadian" are tied to my positionality of a Tamil Canadian immigrant. My migrant family members struggled with ethnicity back home due to the ethnic cleansing of Tamils by Sinhalese militia. I was not concerned about being or representing Tamil in Toronto because I never experienced what it could feel like if I ever lost it. Maybe that's why my family members are so adamant on 
teaching us Tamil daughters how important culture is, as we listen and try to understand their trauma. I realized that managing my "Tamil identity," my “ethnic Tamil identity,” and my "Canadian nationality" is an important aspect of my hybrid self. I have to deal with labels such as "a person of color," "Brown" and/or "Brown girl." This made me aware of the potential challenges of racism and xenophobia to which I may inherently be subject to in everyday life in occupying a less privileged position as an outsider.

On a beautiful sunny afternoon, my best friend and I went to visit her grandma. My best friend is just like me - a Tamil Canadian female, born and raised in Scarborough. I was standing chatting with her when her grandma walked toward us and started talking to us. My best friend and her Ammamah have a great relationship - they talk every day. But today was different. It was a short visit but long enough for her Ammamah to find an issue. My best friend came over to my house the next day and she was furious. Turns out, Ammamah told her she wasn't a fan of the length of the shorts she was wearing. She said, "no offense but it's kind of disrespectful - some of the other residents in the building kept asking me to confirm that you're a Tamil girl and questioned how your mom was okay with you walking out the door like that." I was baffled - have expectations of what Tamil girls should look like extended to other ethnocultural groups of people too? She pointed out her grandma was embarrassed - and also "encouraged" her to stop going out after 8 p.m. My best friend has been afraid to go back ever since she got that comment from her grandma. It made her feel uncomfortable that other people were looking at her as an 'other' to her own culture. We sat there trying to dissect the logic behind her comments but felt defeated anyways. She sat there wondering why she felt ashamed even though she did nothing wrong.

My mom once yelled at me for what I was wearing at a party and the way I was dancing. Apparently Tamil people won't associate with me if I keep presenting myself that way. Apparently parents whose kids do look up to me, will hide them from me if they catch me behaving like that. I forgot I had a family reputation, a culture to uphold. It's not easy. It's not easy being me and it's not easy for the Tamil girl sitting beside you. I am always in conflict with myself as to whether I deserve to be celebrated, or if I am a disappointment to my cultural identity. Maybe I think this way because of the way I was raised, and the constant messages I kept getting drilled in my mind. I don't do what I do to throw away my 
cultural side, and I don't reject values because I hate it. I am trying to show how two worlds can coexist and be celebrated. I know it's hard for people to understand, but I'm trying. I'm trying to be seen as someone besides the cultural "other".

\subsection{Confronting the Third Space}

In my vignette Confronting the Third Space, I describe my life as a young girl negotiating my lack of agency and identity as a cultural hybrid. I habituate the third space as a place that welcomes my cultural hybridity and celebrates the coexistence of my Tamil and Canadian identities. During the times I could be the self that was not determined or dictated by culture, home or society, this third space became my default position. Bhabha's theory (2015) was instrumental and transformational in identifying my own third space as my own natural phenomenon. My third space confronts my exhaustion from having to prove how "Tamil" or "Canadian" I am. I use my third space to hide from the cultural expectations I am expected to carry forward. I claim agency for my sisters, like myself, who fear we don't fit in anywhere in society. But in my third space, I explain how and why we learn to say 'no', and the strength it gives us to immerse into our cultural hybridity. This is the part I celebrate.

I am a second-generation Tamil-Canadian female, I am a daughter. War torn and littered with the bodies of their neighbours, friends and family, my parents leaving their homeland was the only plausible solution for their survival. They brought only the clothes on their backs and the culture that they were taught. For them, adapting to Canada's culture took them several years, as a part of them still held onto the Sri Lankan culture they grew up in since birth.

I never felt like a true Canadian. In my mind, I implemented the idea that to be a true Canadian, I had to leave behind my Tamil heritage. So I would push away anything originating or involving Tamil culture, and in my mind, that's exactly what I did - refusing to go to Tamil class lessons, asking if I could wear a dress to my cousin's puberty ceremony instead of a saree. I would let my nose wrinkle in disgust when I smelled the aroma of our spices in the hallways of Tuxedo Court; and I would whine to my mom when I had to dress up to go to church. 
However, no matter how hard I tried to distance myself from my Tamil heritage, it would sneak up on me, making me feel like an outsider if I failed to greet it. My "Tamilness" sticks with me. I was at a low. All I wanted to be was Canadian, not a Tamil girl, yet I couldn't distance myself from my Tamil culture. All I really wanted was to fit in, to truly be a Canadian - whatever that even means.

Why couldn't I have been born white?

To me, being white meant that you were Canadian, that you were better than everybody else, including and especially being Tamil. Being white meant you fit in, you held a higher importance in society because you got better chances and recognition, you had a freedom, you were allowed to date, and you were allowed to go to parties and stay out late and wear whatever you wanted. So began the series of events in which my self-esteem started to plummet. I just felt so different all the time - conflicted at why my life as a brown girl, a Tamil girl, was so confusing, so restricting, so exhausting. It felt like I was encouraged to live a double life - telling my parents I'm somewhere, when really, I'm in another.

I criticized myself way too often. It wasn't until my sister reached high school that I started to see my heritage under a different light. I remember when my sister was in the ninth grade, in the month of November, my sister asked Amma if she could volunteer for Maaveerar Naal with all of her Tamil friends - a program established to pay tribute to the many Tamil soldiers who lost their lives in the Sri Lankan civil war. This war was fought between the Sri Lankan Military and the Liberation Tigers of Tamil Eelam (LTTE). During this time, over 300,000 Sri Lankans migrated from Sri Lanka to Canada, including my parents. However, many family members of these Tamilian immigrants and refugees decided to stay; they wanted to protect their homeland and pave the way for their families to flee in safety. I knew that many of my other Tamil families came to Maaveerar Naal to mourn and pay homage to the Tamils who fought in the war. To be a part of the effort that was engrained in my cultural history, Akka told my mom that she would volunteer. Even though we take part in this event, my eyes opened up for the first time I saw Akka in the tent with thousands of other Tamils who attended. I saw so many children and young people. I realized right then and there that I should have pride in saying that I am a young Tamil woman. 
Integrating certain cultural aspects into my life was incremental - I didn't know where an appropriate place to start was, so when Amma asked me to start talking in Tamil with all my elder relatives - rather than whining and complaining like I normally did whenever she'd ask, I actually listened. The conversations I began to understand about Tamil culture and religion, inspired me to try and delve deeper into our roots. I started by researching about the scientific reasoning of our customs and traditions, most of which my cousins and I used to dread.

Throughout my teen/young adulthood, researching and asking questions to my Tamil migrant family members (at times) made me feel closer to my Tamil heritage. I realized then that many second-generation Tamil-Canadian daughters like myself felt as though they needed to choose between acting upon Canadian culture, or Tamil culture, and wishing they didn't have their Tamil heritage in the first place. We don't want to be "too Tamil", which is evident because many of us feel embarrassed when we take something as simple as lunch out during school or walking around the mall with our Panjabis after coming from church or the temple. We also don't want to be considered "whitewashed" when we don't know how to pronounce something in Tamil (which happens to me almost every conversation I have with a relative). Like myself, many second-generation Tamil-Canadian daughters fought and continue to fight this identity battle within themselves. The hardest days are when we don't listen to what they tell us to do. You know, I'm not a bad kid - I'm really not. I don't go out late at night, I go to every family/religious event, I serve my uncles food first ... but sometimes it gets hard. Especially when I haven't seen some relatives for a long time and their first questions are: You gained so much weight, are you going out late at night? You lost so much weight, are you not eating enough rice and curry? I saw you talk to a boy on the subway a month ago, is he your boyfriend, Do Amma and Appa know? How old are you now? You're almost 22, any plans for marriage? How come you're not married yet? பெண்கள் விரைவாக

\section{திருமணம் செய்து கொள்ள வேண்டும் - நீங்கள் காத்திருந்தால் அது} எதிர்காலத்தில் மிகவும் கடினமாகிவிடும் [girls must get married quickly - if you wait it'll get too hard in the future]. 
Akka had it really hard - especially being the eldest daughter in a family that our Tamil community here in Scarborough looks up to. Sometimes she tells me that she doesn't mind when people tell her she has to get married soon. Those conversations started for her when she turned 15 - at first she shook it off, but when she was in her early 20's it started to make sense to her. She's 25 now, but she still doesn't feel like the pressure's "totally" - I think it's because all of her Tamil girlfriends are all in the same position as her, dealing with the "marriage conversation". For some it doesn't matter to them because they all have boyfriends who they know they'll eventually get married to, but for Akka, my parents and our surrounding community expects her to get an arranged marriage. My sister doesn't know when she's going to get married and that's okay; but all our community Tamil members feel the need to always nag her about it. She never has an answer for them because she genuinely doesn't know when she wants to get married. I remember when Akka had her first proposal. It was so weird because we didn't even want to meet the guy after what we heard about him. But she said yes to meeting him anyways. She was scared - it was a surreal moment where she felt like she could see her whole life flash before her eyes like, "crap-I'm so screwed". Meeting him was whatever for her because she already decided she was going to say no, and since no one at home talked about it after he visited, Akka assumed it was a no. But when Appa brought it up two weeks later and said he didn't say no to his family yet, that's when Akka got really scared. She felt unsettled. She didn't like how she was experiencing this so much sooner than she could have prepared for.

I asked Akka if she was scared to tell Amma and Appa 'no' - even growing up, they put way more expectations on her and would say "no you can't go out, you can't do this, you have to do this" and every time that she would say no to them, how did that make her feel - did she feel like a bad daughter? She always tells me that she only feels like she's voicing her concern, and to this day she still can't wrap her head around why they always say no to her so often, she doesn't get it. It's okay to say 'no' once in a while, but it almost felt like, when Akka was growing up and in high school, they said no to everything. She genuinely wasn't allowed to do anything. Even now she feels like she has to lie for everything, like "oh I'm just going to the mall" even though she's actually going to hang out with her friends who aren't part of our community. That's probably why she has to tell us she has night shifts 
because she just wants to go out and have fun for once. That's one of those things where you never feel listened to - like your perspective is never taken into consideration. Not necessarily neglected, but our family members are unbothered by the way you feel - like it's irrelevant to the situation and that's always a shitty feeling. It's something that hasn't changed since we were kids. Even when we were planning things for our friend's wedding, the idea that our parents might say 'no' really pisses me off. It makes us want to fight them and lash out and be aggressive and be rude.

Why do I think they'll say no? I honestly feel like for us it's a different situation because Appa is such a well-known and respected leader in the Tamil community we identify with here in Scarborough. The aspect of protection is there, they want us to be safe; but your safety is always at risk whether you travel at $1 \mathrm{a} . \mathrm{m}$. home from work or $1 \mathrm{a} . \mathrm{m}$. home from a party. But 1 a.m. home from work is something Akka does all the time, and its nothing to them. They'll sleep, no worries no problem. But being out because I'm at a party at my friend's house all night, or until 1, is a scary thing to them and I honestly feel like that's a community associated thing - they're scared about reputation. They're scared about "what IF a community member catches her, what IF somebody sees her" they don't want that. Because you never really get a proper 'no' explaining why it's a 'no' - it's always a straight 'no' - 'I said no; Amma said no; Appa said no". But it's always been like that. When Highschool Musical premiered Akka really wanted to go to her friend's house and watch it because all her friends were meeting there, but Amma and Appa said no, she wasn't allowed because “girls aren't allowed to wander off into random houses - it doesn't look good." It breaks my heart when my 25-year-old sister bears and still carries the trauma of her 13-year-old self.

Reputation is one of the biggest reasons behind why they say 'no' and hold all these rules against us. That, and lack of trust. No matter how much Tamil parents, and I think this is across the board regardless of religion - no matter how much across the board they raise us and they try to instill morals and values into us, they don't trust us daughters, that we're going to carry it out. The still feel like we're going to be disrespectful and act inappropriately or behave inappropriately. They have to trust the way they've raised us daughters. Especially when they get to a certain age - I don't get why Akka is 25 and I'm almost 23 and we still have so many restrictions in comparison to our non-Tamil friends. It's embarrassing, and 
breaks my heart, when my best friends just go out without me because they know Amma and Appa will say no to me going out; and sometimes I don't even want to ask Amma and Appa because I'm scared to hear them say 'no', and I'm even more afraid to reject what they tell me to do because I don't want to feel more alone than I already do.

I guess in this case, the point that I'm trying to make is that it's harder for Tamil daughters because they see us as the ones to carry culture. I think we will carry it because we love to dress culturally, we love eating our food, we respect our elders - without even any hesitation, you meet community members and you say 'Aunty/Uncle', you don't say anything in regards to their name. If you meet anyone older than you, you say 'Akka' 'Anna' - it's natural. I think that's the type of thing we will carry. We all speak Tamil - we may not be good at it, but we can at least carry a half conversation. We will carry our traditions forward, but again, they don't trust it and they're scared we're going to lose it. I don't blame them for it, but that doesn't mean you can put restrictions on your daughters in an effort to force them into a certain lifestyle.

Rather than wasting our energy trying to prove how "Tamil" or how "Canadian" we are to each other, our migrant community members should be more open and forthcoming to each other about the conflicts we face, such as how there's this fear of us daughters losing and rejecting our Tamil culture our parents have taught us. It only makes it worse for us - now we fear that we don't even fit in anywhere in society, and that we are constantly being judged. Some days, to avoid all of this confusion, we wish that we could have been born white. Us opening up to each other can finally make us realize that at the end of the day, we all face the same difficulties and it's okay to struggle. Every time one of us steps forward to talk, the bond between each of us strengthens; and with that, the union between young TamilCanadians is fortified. We all become stronger - individually and as a group - when we come together. 


\section{CHAPTER FIVE}

\section{Discussion}

This study aimed to address three main objectives around exploring hybridity and identify negotiation of young Tamil Canadian women:

1. How does cultural hybridity influence how young Tamil Canadian women select/reject certain cultural practices?

2. What is the impact of their choices on familial/community relationships?'

3. To what degree do existing theoretical concepts - e.g. hybridity theory, cross-cultural psychology, third space - adequately capture my lived experiences in navigating hybrid cross-cultural identities?

It was after garnering a passion for social justice and feminism that I came to realize the existence of a great deal of misogyny and sexism in the male-dominated Tamil diaspora. After some years, you would expect there to be a change in the way women are portrayed as 'carriers of culture', but I feel as though it has somehow worsened. Rethinking acculturation in the context of diasporic identities and from a gendered perspective is important for this research. The overarching literature that dissects diaspora studies and new forms of cultural identity is valuable to this research as it provides a dialogical approach to understanding how South-Asian Canadian women living in diasporic locations negotiate their multiple and often conflicting cultural identities.

A common topic revisited in my vignettes is the cultural view that Tamil daughters ought to get married in order to fulfill the life mapped out for them. Mehrotra (2016) speaks about South Asian women and marriage, and how a number of authors have assumed the importance of gender, marriage, and family within South Asian diasporic culture without hearing from South Asian women directly with respect to their own lived experiences and perspectives. Through interviews with South Asian women living in the U.S., Mehrota shows that across generations, messages about (heterosexual) marriage emerged as central to how women understood their gendered experience and, as such, marriage and being marriageable function as a "cultural script'" for middle-class South Asian womanhood (Mehrota, 2016). Women's narratives from 
her study elucidate some of the specific messages of this "cultural script"' and everyday ways this script is indirectly and directly communicated to women within family and community interactions (Mehrota, 2016). Although this study takes place in the U.S. and generalizes South Asian women into one subject, this example is very parallel to the Sri Lankan Tamil mentality of marriage and is one of the most oppressive "scripts" Tamil daughters are expected to adhere to. Aforementioned, while the importance of gender and family in South Asian culture has often been assumed within scholarship and communities alike, little research has been done to understand South Asian women's lived experiences from their own perspectives or across generations (Mehrota, 2016), thus justifying the need for an autoethnographic approach. Much of this literature remains conceptual or based in macro-level analysis. I take the position that growing knowledge about diaspora and gender involves not only the macro analysis of globalization and migration but also attention to the everyday narratives of social relationships, lived experiences, and embodied practices that make up the lives of individuals, families, and communities.

There are always theoretical, methodological, political, and practical challenges to building knowledge about any minoritized group within a majority culture. As a South Asian feminist scholar, I, like Mehrota (2016), grapple with the potential of perpetuating stereotypes or promoting the exoticization or essentializing of a particular cultural experience of gender and marriage. "Being Marriageable" is a hot topic at the dinner table of a Tamil household. Mehrota explores this topic and provides agency for women who were also brought up in such cultural views. In addition to the inevitability of marriage, being married by a particular age, and messages about who to marry, women also spoke about learning about what it meant to be "'marriageable'. In these women's narratives there was simultaneously the assumption that adult women should be married, and "that there are certain criteria you have to satisfy in order to be nicely eligible to be marriageable', (Mehrota, 2016) as a South Asian woman. Marriage was defined by physical beauty (particularly being light-skinned and thin), being successful in one's career (especially if not seen as physically attractive) and being able to perform the role of a daughter-in-law. This message of the "cultural script", that "being pretty is necessary to getting a good husband", is repeated in various ways in Tamil households, as well as the lives of Mehrota's South Asian participants. 
Mentioned in the beginning of the paper, the roots of the 'good Tamil daughter' come from the traditional Hindu construct of the 'good woman' as one who is "married and auspicious (sumangali)" (Gowrinathan, 2012). The construction of the Tamil wife is linked to a construction of the mother figure, which is often relied on as a symbolic representation of national and communal identity in South Asia. (Rajinisingham-Senanayake 2001). Marriage, its practice and customs, in itself have been culturally repressive in the Tamil society. As a daughter to a strong Tamil religious leader, I was raised with similar expectations, and while this placed me on the outside of mainstream "Canadian" society, it was overbearing. Older and younger girls in my diaspora would be shocked at the size of my earrings, chastise me for wearing a light-colored skirt that had the possibility to be transparent, judge my character for showing cleavage, and/or despise me for hugging boys my age. The symbolic positioning of the Tamil woman through Hindu mythology, or cultural norms is particularly relevant for their eventual positioning within this discourse, as it continues to be passed on from generation to generation. (Gowrinathan, 2012; De Mel 2001; Rajinisingham-Senanyake 2001). 40 Days and 40 Nights, touches upon the onus my father believes is his - to ensure I am a "good Tamil daughter". When I argue with my parents against the notion that I must fit a criterion before the age of 25 in order to be eligible for marriage, I question why no one talks about the kind of husband we should marry. Why are very few expectations placed on Tamil son's? Daughters are expected to be beautiful, be well educated, have a stable job, be able to provide financially, etc., however, there is a large gap in the conversations surrounding Tamil sons and what is expected of them to bring to the culture and what they should practice. In He's Wrong, I was able to articulate how daughters shouldn't strive to be 'successful' or else someone else's son will not want to marry her. Daughters are expected to take care of the husband and kids, but daughters are not taught how to communicate when/if they need help from a man/a husband. "Tamil parents know if they raise their daughter to be successful, finding her a husband will be hard - no one wants a woman who outshines their son" - is an enforcement of the cultural script — particularly as it emphasizes power of the male over the female.

In my vignette, Confronting the Third Space, I am able to reference Mehrota's study, as her findings sound similar to the voice of my sister - as she talks about how domesticity was highly valued as a part of being marriageable and becoming a daughter-in-law. "When asked 
what she learned growing up about being a South Asian woman, she recounts the importance of being trained to be a daughter in law" (Mehrota, 2016). Marriage as inextricably linked to family roles, particularly being a daughter-in-law, was a sentiment shared by many interviewees of her study and is shared among Tamil daughters of my own diaspora. Enforcing the relationship between the cultural script, gender, and one's place in the kinship structure is important to note here since little research has been done to understand South Asian women's lived experiences from their own perspectives or across generations.

Upon analyzing Discovering the Third Space and the Cultural "Other", I draw on the concept of "banal nationalism" (Amarasingam et al., 2016) as a theoretical tool for analyzing the production of nationalism in the everyday life of second-generation Tamil youth. Drawing on Amarasingam's interviews and focus groups, Tamil youth born in Canada discussed multiculturalism might actually encourage cultural fragmentation and social isolation from their migrant family members. This analogy is very much representative of young Tamil Canadian female who are socially isolated/fragmented from their diaspora for incorporating Canadian 'multiculturalism' into their negotiation of identity. Despite all the criticism they continue to receive from their migrant family/community members (for identifying themselves as Canadian), second-generation Tamil youth sampled in Amarasingam's study (2016), consider themselves as Canadian because of a "lack of feeling loved" by a Sri Lankan nationalistic house practiced by their parents. In Discovering the Third Space and the Cultural "Other" I talk about how my family members would get upset if I play with my non-Tamil friends, and how they perceived that as a "betrayal" to my Tamil network. Our parents have such a large fear, that if we daughters, decide to mingle with anyone who is not of our ethnicity/cultural background, then we will lose the identity they approve of. In reference to Table 2, I state my inability to pursue friends from school due to parent's beliefs of racial/gender differences, is a disruption in my maturation and development process. The negotiation of my identity becomes stressful, and depletes my self-esteem, because as I continue to pursue these friendships, I receive backlash from my family and migrant community members. I am "othered" by my diaspora, viewed as a "betrayer". 
While a participant from Amarasingam's study recounted experiences of xenophobia and racism related to her religious identity and her activism in Canada around developments in Sri Lanka, she never argued that Canada was home:

“A lot of people don't understand Hinduism... and so I felt like kids made fun of me [in Canada]. They would say, 'oh, you worship an elephant'. Or something like that. Like kids very openly made fun of me. Especially when the conflict in Sri Lanka was, you know, escalating. People would make fun of me, they were like, 'Terrorist. Your family are probably terrorists'. Things like that.

Interviewer: So, you know, having gone through this experience with feeling very othered in the communities here, do you feel at home in Canada?

Ya, I have family here. I have friends here. I have people who care about me here. I know it's like, you know culturally, historically if I don't fit in here, I'm not going to feel loved in Sri Lanka. I feel loved here, and that's nice. And I feel like, especially in a place like Toronto, it's easy to build relationships, because people don't really see the colour of your skin. They do, but that's not like what makes you friends, or makes you fall in love with someone. It's your personality." (Amarasingam, 2016).

Whether respondents experienced discrimination in Sri Lankan households while growing up or felt unwelcome during family visits, most respondents expressed an overall sense of inclusion and security outside of their homes, with the multicultural Canadian community (Amarasingam, 2016).

Some studies are more optimistic about their findings in relation to multiculturalism in Canada. Nagra and Peng (2013) argue, that being transnational should be normalized in diasporic communities. Quite interestingly, many experiences of Tamil Canadian youth in previously reviewed literature articulate that some are able to overlook the stigma they receive from nonethnic peers or those in their own diaspora. They embrace their multiculturalism and transnationalism. In reference to the excerpt from Amarasingam's participant, they felt that the broader culture of Canada would stand by them regardless of moments of racism/xenophobia because they acknowledge Tamil Canadian youth's efforts of assimilation. I suggest that Tamil Immigrant parents tend to feel offended by individuals who questioned their nationalism to their home country during their own individual assimilation to Canadian society. Therefore, they reject this notion of "multiculturalism" operating in the lives of their children. That being said, in Confronting the Third Space, I argue that our migrant community members should be more open 
and accepting of the multiculturalism - the cultural hybridity that operates in their daughters' lives.

Hybridity becomes a thematic point of discussion across my vignettes. Wake (2018) uses an autoethnographic approach to articulate how she has been immersed within the symbiotic hybridity of two cultures. Kraidy (2005) asserts that hybridity is "the obligatory celebration of cultural difference and fusion and it resonates with the globalization of mantra of unfettered economic exchanges and the supposedly inevitable transformation of all cultures" (1). However, there are various approaches to hybridity. For instance, Werbner and Modood (2015) explain it as "a 'mixture' of two discrete, and hence bounded, 'cultures"” (14). To embrace a critical approach to hybridity, Kraidy (2002) explains it as a "mode of lived experience" and a communicative practice for exploring the politics of marginalized subjects" (332-333). Bhabha (2015) asserts that hybridity "has established its salience in a wide range of discourses relevant to the aesthetics of cultural difference and the politics of minorities" (9). Similarly, I am interested in theorizing about how hybridity illuminates my lived experience of identity performed across cultures at the intersections of various facets of my selfhood: Brown, female, Sri Lankan, Tamil, Canadian, diasporic, second-generation immigrant, and so on.

These realities provided the context to Wake's autoethnography as a second generational daughter of southern Italian migrants. The narratives within are evocative forms of expression describing her lived experiences. They provide evidence highlighting the implication of living as a female cultural hybrid dominated by familial, patriarchal and religious conventions, fittingly parallel to my study.

Wake writes vignettes that were factual because they drew on her own account of existing experiences in four short stories. Barriers and Borders describes the personal experiences of migration for both her parents, but in particular her mother. No Man's Land, relates the initial impact of cultural identity experienced in her childhood and as a school girl who did not fit in because of her appearance and nationality, and who had to adhere to strict familial life as a daughter within a culture where female gender was governed to domesticity. All Grown $U p$, characterizes her experience and inability to develop her personal identity within the space of cultural hybridity. Lastly, Searching for Self, which like Discovering the Third Space 
and the Cultural "Other" reveals our confusion of what roles to assume on a daily basis (Wake, 2018). Every vignette of Wake's demonstrates insights of cultural hybridity and how cultural capital was dominant in determining the impact on her educational trajectory. "The opportunity to explore and advance my life experiences through narratives has enabled me to reflect and make sense of my identity and culturally determined life recounted in my own creative style evoked by memorable visions of the past infused within all my senses" (Wake, 2018). Her research question, "How has cultural capital and hybridity shaped my educational/life trajectory as a second-generation Italian Australian woman?" and my own research question 'How does cultural hybridity influence how young Tamil Canadian women select/reject certain cultural practices? What is the impact of their choices on familial/community relationships?' necessitated writing narratives that rationalises the inequalities immigrant daughters face between two cultures. This in turn serves to identify motives of a society, culture and family towards the value of cultural attainment specifically for daughters of Tamil migrants, just as Wake's explored for daughters of southern Italian migrants.

All my narratives in this piece, highlight intersecting ways of being "different" that afford the opportunity for more theorization on hybridity as a tool for promoting new subjectivities for hybrid immigrants in the acculturation context. The three themes, hybridity, identity negotiation (the "good" Tamil daughter) and the third space, demonstrate how cultural hybridity challenge my authentic self and position my dialogical self across the Tamil Canadian narrative. I personally learned from all these performances that as a diasporic subject, my identity is always in a state of becoming, which in turn allows me to embrace self-authenticity as the ability and the legitimacy to define myself and create what it means to be a Tamil Canadian daughter. Ultimately, through this process of storytelling, I gained a sense of agency. I used my lived experience as a series of selected stories to expand theorization of cultural hybridity to the peculiarities of Tamil Canadian culture. Therefore, the stories provided here as self-reflexive accounts of my lived experience are not separate from theory; but align with the hybridity theory in which I have adopted as a framework.

When drafting these stories, some of the struggles I came across was tying my hybrid identity into the creative process. An important step in this process was editing and revising and making decisions about what content was worth adding in, and even more difficult, having to let 
go of excerpts I felt passionate about for the sake of clarity of length. The aim of my vignette writing was for the reader to be able to experience the emotions and lived experiences of my life. It was important to me that my voice could be heard alongside every word one reads; that it becomes alive and real. I incorporate bilingualism into Introductory Vignette, 40 Days and 40 Nights, Discovering the Third Space and the Cultural "Other", and Confronting the Third Space where particular phrases/sentences are in my mother tongue, Tamil. I chose to write those particular sentences in Tamil - (a) as an opportunity to introduce my mother tongue into academic literature due to the lack of familiarity of the language and its alphabetical script, (b) to utilize the language that was almost ripped away from my family members who fled to this country from the Civil War, and, (c) to illustrate to the reader that some statements our parents say are always lectured at us in Tamil as opposed to English because it has a greater emphasis.

There were moments where these pages became a place for me to vent, and I had to come to the realization that my narratives should not emotionally exhaust the reader by being a burden to read/follow. It was important I placed my theoretical frameworks at the core focus of each vignette, so that it helps interpret the meaning/significance of my vignette. I hope my research is accessible to various members of my family/diaspora, which is why I find it important that my raw emotions are not misunderstood as accusations or "complaints" about my culture. I appreciate the Tamil culture - its journey across the world, the process of its rebirth after being demolished by Sinhalese militia, the beauty in the language, arts, familyhood - but I believe it is my onus, as a Tamil daughter and researcher, to fill in the missing discourse on second generation Tamil female and how we explore hybridity and identity negotiation.

I typically use the term daughters as opposed to women, because I perceive the term daughters replicable of how I position myself in the Tamil diaspora. Therefore, for the purpose of this autoethnographic study, I like to refer to my Tamil sisters as daughters since I concur it is in that position that we find the most difficulty exploring our hybridity and identity negotiation. The term daughters place a sense of vulnerability among us, which I believe evokes sympathy from the reader, and justifies our need for agency. I thematically relate my narratives to cultural hybridity, cross-cultural psychology and the third space, as a means to scaffold the distinctive and significant objectives of my autoethnography. Within my narratives titled Discovering the 
Third Space and the Cultural "Other" and Confronting the Third Space, I adopt theorist Bhabha's concept of a "third space" to adequately capture my lived experiences in navigating hybrid cross-cultural identifies. Within my narratives Who are you I weave in Bhatia \& Ram's (2004) discussion of culture, self and the stress of acculturation within the context of crosscultural psychology. I make a simple statement that I exist in alignment with culture, and/or detach myself from culture and mix with other cultures, "I position myself as a cultural hybrid subject - someone who encompasses cultural practices and values from two different areas of the world. I identify as Tamil but act Canadian - and that doesn't have to make sense to you" - I am not bound to one culture only but can move and exist in more than one culture at the same time, "I am indeed a transnational subject. I live in Toronto, Ontario - Scarborough, mini Jaffna is what I call it. I belong to here and there. Each of these identity layers is intertwined and impacts my lived experience in everyday life."

The impact of my choices to select/reject certain cultural practices, on familial and community relationships (i.e. refusing to get married by age 25), applying a dress code into my everyday life etc., has evidently "othered" me, by not only my relatives/migrant community members, but other non-Tamil residents who have learned such presumptions of Tamil daughters.

Measuring the degree to which the aforementioned theoretical concepts adequately capture my lived experiences in navigating hybrid cross-cultural identities presented a challenge, due to its complexity. Therefore, I adopted Wake's (2018) delineation of stages of her life that are at odds with Erikson's theory of arrested development of psychosocial and maturation milestones. In order to understand and put into context the many cultural expectations that shaped my life, Wake (2018) suggests it is essential to acknowledge the attitudes of the individual which are borne by the synthesis of familial and cultural norms. Linking the stories of my upbringing and the stages of my comparative table of psychosocial and maturation milestones to Erikson's 5th Stage theory establishes the reality of thwarted agency to develop my own attitudes, as I did not possess my own subjective developed identity (see Table 1). 


\section{CHAPTER SIX}

\section{Conclusion and Recommendations}

Recognizing the notion of living in the third space has allowed me to explore specific situations of the Tamil diaspora here in Toronto. It has become possible to grasp connections, relations and similarities, as well as disconnections and differences, among Tamil Canadian women. While my autoethnography explains how Tamil immigrants experienced a moment of crisis in their everyday lives that invoked traditional rituals, things, gender- and transnational relations, I have argued that the migrating ritual and performance of abiding by certain cultural practices are placed upon the responsibility of the second-generation Tamil Canadian daughter. As a Tamil Canadian daughter, myself, and an active member of the Tamil diaspora in Toronto, I was motivated to embody and represent the emotional issues of gender and womanhood, social and moral hierarchy, identity and belonging, as I faced disruptions, critical events and everyday challenges in key developmental stages of my life (see Table 2). Such linkages can be embodied, negotiated and debated differently, generating individual and community experiences of belonging, wellbeing, alienation, rebellion, dispute and conflict.

My autoethnography serves to acknowledge the diaspora of my parents as Sri Lankan migrants to Canada, who worked hard to recreate their culture in a Country so foreign to their home. This knowledge is in context to my autoethnography presented in this paper and frames the beginning of my life as a second generational daughter of Sri Lankan Tamil migrants. Findings within this autoethnographic study clearly demonstrate the implications of living as a female within a hybrid culture dominated by patriarchal (and religious) culture. The research literature assists to scaffold my narratives situating each story and related phenomenon as data in order to contribute new knowledge in relation to the implications that cultural hybridity may have for future second generation daughters of immigrant parents. The significant contribution of my autoethnography to existing knowledge is that the findings identified causative factors related to my parent's immigration, strong cultural and religious practices, and position of power within the Tamil diaspora, as facilitators for my chronologically disrupted development as an adolescent. My development was compared to Erikson's fifth stage of psychosocial development highlighting vital milestones missed due to the intense degree of cultural expectations placed on 
me, disrupting my ability to transition into adulthood, claim independence, and have control over my identity.

My narratives also provided insight into how my identity was primarily compromised due to cultural hybridity and gender compelling me to seek out a familiar sanctuary in what Rutherford (1990) described as Bhabha's “third space.” Autoethnography was instrumental in perpetuating reflective self- examination into self-authenticity, thus becoming an obsessive component of my cultural and developmental knowledge and research.

Limitations to this research could be that the knowledge from my autoethnographic study may be irrelevant to Tamil female daughters who migrated to Canada at a young age (e.g. 6-10), who might benefit from further research relating to different theories which address power imbalances associated with cultures and race, as this paper focuses solely on Canadianborn/second-generation Tamil Canadian daughters. Another limitation is that this study is largely derived from my own lived experiences which is, on one hand a strength, but it isn't meant to be generalizable. My recommendation for future research is to pursue this study with a larger sample. Interview style data collection methods may further justify the phenomenon I have explored. Other narratives from second-generation Tamil daughters could drastically enhance the quality of my findings. Further qualitative research is recommended to be undertaken across Toronto in an effort to identify if there are other cohorts of daughters of Sri Lankan Tamil parents who have had similar experiences of disruption in their development during their adolescent years, due to strict cultural rules and trauma when negotiating their identities. The research questions would apply with the objective that the data may contribute new knowledge to the existing research for Tamil daughters.

Some ways to enhance the quality of existing literature would be to dissect the feeling of fear first generation immigrants face - fear that their culture will disappear during assimilation to Canada. Literature on fear of vanishing culture, and, the preservation of culture through second generation youth would develop a better understanding behind the cultural-oppression/pressure young Tamil Canadian women might be facing in Toronto. Predictors of parent-adolescent relations in the Toronto Tamil community that discuss the discourse of intergenerational cultural dissonance among immigrant families would also add depth to this study. However, literature on 
Tamil Canadians is very limited, and more research must be conducted to create new sources that will discuss the clash between parents and children over cultural values.

My autoethnography is the suggestion that the dominance of both cultures - Tamil and Canadian - at all stages during my childhood and adolescence were instrumental in regulating and ruling my situated position as a daughter who possessed a hybrid cultural identity with no opportunity to develop a true sense of agency or to explore and shape my identity at any stage of my adolescence. What this autoethnography also exhibits is that my stories are powerful - they demonstrate lives affected by diaspora, isolation from both cultures, conscious and unconscious fears which guided the parenting practice within my family combined with the limited independence to explore my authentic self in my adolescent history. The opportunity to present my narratives in an autoethnography and share my personal biography as a means to identify gaps and milestones throughout my adolescence as research and for the purpose of extending knowledge and sociological understanding (Sparkes, 2000) allowed me the subjectivity to represent myself as an unbound woman who has liberated myself from the shackles of self-doubt regarding my cultural hybridity and identity. I hope this research may inform and assist my community members of my diaspora, as well as educators and academics who seek to further understand culturally diverse complexities within specific hybrid cultures compared to that of a monoculture. 


\section{Appendix}

\section{A. Table 2. Arrested Development of Psychosocial and Maturation Milestones of Rose Wake}

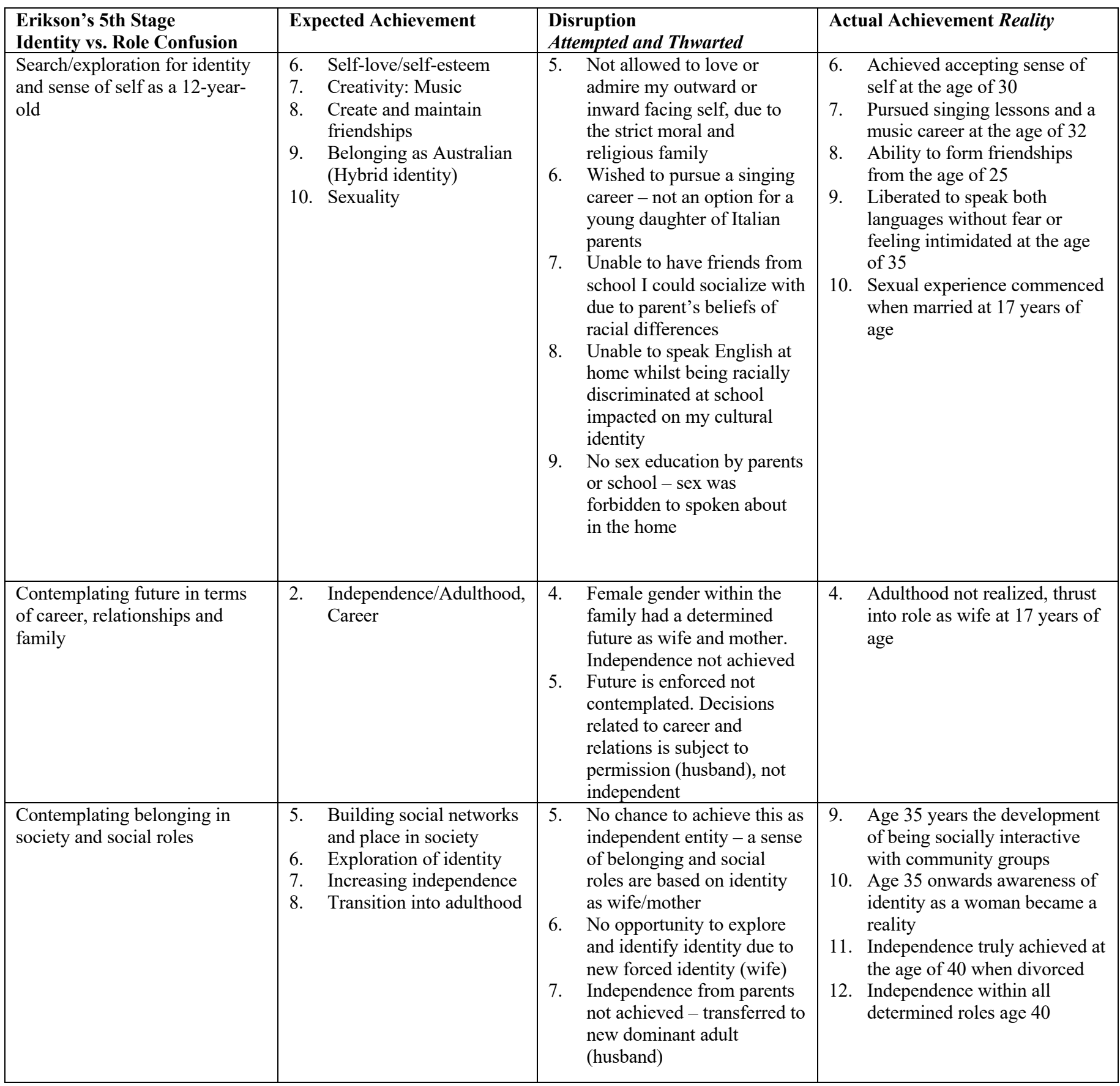




\section{References}

Adams, T., Ellis, C., \& Holman Jones, S. (2015). Autoethnography: Understanding qualitative research. New York, NY: Oxford University Press.

Alexander, K. B. (2014). Critical autoethnography as intersectional praxis: A performative pedagogical interplay on bleeding bird-ers of identity. In Nziba Pindi, G. (2018). Hybridity and Identity Performance in Diasporic Context: An Autoethnographic Journey of the Self Across Cultures. Cultural Studies $\leftrightarrow$ Critical Methodologies, 18(1), 2331. https://doi.org/10.1177/1532708617735636

Amarasingam, A. (2015). Pain, Pride, and Politics: Social Movement Activism and the Sri Lankan Tamil Diaspora in Canada. Athens, Georgia: University of Georgia Press.

Amarasingam, A. \& Naganathan, G. \& Hyndman, J. (2016). Canadian Multiculturalism as Banal Nationalism: Understanding Everyday Meanings Among Sri Lankan Tamils in Toronto. Canadian Ethnic Studies 48(2), 119-141. Retrieved from, https://muse-jhuedu.ezproxy.lib.ryerson.ca/article/629461

Barber, J. G., \& Delfabbro, P. (2000). Predictors of Adolescent Adjustment: Parent-Peer Relationships and Parent-Child Conflict. Child and Adolescent Social Work Journal, (17)4. Retrieved from, https://link-springer-com.ezproxy.lib.ryerson.ca/article/10.1023\%2FA\%3A1007546023135

Bardhan, N. (2011). Slumdog millionaire meets "India shining": (Trans)National narrations of identity in South Asian diaspora. Journal of International \& Intercultural Communication, 4, 42-61.

Bardhan, N. (2012). Postcolonial migrant identities and the case for strategic hybridity: Toward "inter" cultural bridgework. In N. Bardhan \& M. P. Orbe (Eds.), Identity research and communication: Intercultural reflections and future directions (pp. 149-164). Lanham, MD: Lexington Books.

Berry, J. W., \& Sam, D. (1997). Acculturation and adaptation. In J.W. Berry, M. H. Seagull, \& C. Kagitçibasi (Eds.), Handbook of cross-cultural psychology: Social behavior and applications (Vol. 3, pp. 291-326). Retrieved from, https://ebookcentral-proquest com.ezproxy.lib.ryerson.ca/lib/ryerson/reader.action?docID=4949633

Bhabha, H. K. (1994). The Location of Culture. New York: Routledge. Retrieved from, https://books.google.ca/books?id=p7quDTSmYRYC\&printsec=frontcover\&source=gbs_ge_sum mary $\mathrm{r} \& \mathrm{cad}=0 \# \mathrm{v}=$ onepage $\& \mathrm{q} \& \mathrm{f}=$ false

Bhabha, H. K. (2015). Foreword. In P. Werbner \& T. Modood (Eds.), Debating cultural hybridity: Multicultural identities and the politics of anti-racism (New ed., Critique Influence Change, pp. ix-xiii). London, England: Zed Books.

Bhatia, S., \& Ram, A. (2004). Culture, Hybridity, and the Dialogical Self: Cases from the South Asian Diaspora. Mind, Culture and Activity, (11)3. Retrieved from, https://journals-scholarsportalinfo.ezproxy.lib.ryerson.ca/pdf/10749039/v11i0003/224_chatdscftsad.xml 
Bhatia, S., \& Ram, A. (2009). Theorizing identity in transnational and diaspora cultures: A critical approach to acculturation. International Journal of Intercultural Relations, 33(2), 140-149. doi:10.1016/j.ijintrel.2008.12.009. Retrieved from, https://journals-scholarsportalinfo.ezproxy.lib.ryerson.ca/details/01471767/v33i0002/140 tiitadcacata.xml

Chatterjee, P. (1989). Recasting Women: Essays in Colonial History. Eds. Sangari, K., \& Vaid, S. (1992). Retrieved from, http://jan.ucc.nau.edu/ sj6/Sangari\%20and\%20Vaid\%20Introduction.pdf

Choi, Y., \& He, M., \& Harachi, T. W. (2008). Intergenerational Cultural Dissonance, Parent-Child Conflict and Bonding, and Youth Problem Behaviors among Vietnamese and Cambodian Immigrant Families. $J$ Youth Adolesc, (37)1. Retrieved from, https://www.ncbi.nlm.nih.gov/pmc/articles/PMC2475652/

Creswell, J.W. (2013). Research design: Qualitative, quantitative, and mixed methods approaches. Thousand Oaks, CA: Sage. (pp. 1-24). Retrieved from, https://reserve.library.ryerson.ca/ares/ares.dll?SessionID $=$ P025931480L\&Action=10\&Type $=10$ $\underline{\& \text { Value }=269973}$

De Mel, N. (2001). Women and the Nation's Narrative: Gender and Nationalism in Twentieth Century Sri Lanka. New Delhi: Kali for Women. Retrieved from, https://books.google.ca/books?id=h0f_D1qiXQgC\&pg=PA57\&source=gbs_toc_r\&cad=4\#v=one page $\& q \& f=$ false

Dunkel, C. S., \& Harbke, C. (2017). A review of measures of Erikson's stages of psychosocial development: Evidence for a general factor. Journal of Adult Development, 24(1) 58-76. Retrieved from, https://link-springer-com.ezproxy.lib.ryerson.ca/article/10.1007/s10804-0169247-4

Fleer, M. (2006). The cultural construction of child development: Creating institutional and cultural intersubjectivity. International Journal of Early Years Education, 14(2), 127-140. doi:10.1080/09669760600661294. Retrieved from, https://journals-scholarsportalinfo.ezproxy.lib.ryerson.ca/details/09669760/v14i0002/127_tccocdciaci.xml

Godiwala, D. (2007). Postcolonial desire: Mimicry, hegemony, hybridity. In J. Kuortti \& J. Nyman (Eds.), Reconstructing hybridity: Post-colonial studies in transition (pp. 59-79). Amsterdam, The Netherlands: Rodopi, B.V. Retrieved from, https://zodml.org/sites/default/files/\%5BJoel_Kuortti\%2C Jopi_Nyman\%5D Reconstructing_H ybridit.pdf

Gowrinathan, N. (2012). How women rebel: Gender and agency in Sri Lanka. UCLA: Electronic Theses and Dissertations. Retrieved from http://ezproxy.lib.ryerson.ca/login?url=https://searchproquest-com.ezproxy.lib.ryerson.ca/docview/1022305031?accountid=13631 
Grønseth, A. S. (2018). Migrating Rituals: Negotiations of belonging and otherness among Tamils in Norway. Journal of Ethnic and Migration Studies, (44)16. Retrieved from, https://journalsscholarsportal-info.ezproxy.lib.ryerson.ca/pdf/1369183x/v44i0016/2617_mrnobaoatin.xml

Grossberg, L. (1996). Identity and cultural studies: Is that all there is? In S. Hall \& P. du Gay (Eds.), Questions of cultural identity (pp. 87-107). Thousand Oaks, CA: SAGE. Retrieved from, http://pages.mtu.edu/ jdslack/readings/CSReadings/Grossberg_Identity_Cultural_Studies_Is_All _There_Is.pdf

Hall, S. (1990). Cultural identity and diaspora. In J. Rutherford (Ed.), Identity: Community, culture, difference (pp. 222-237). London, England: Lawrence \& Wishart. Retrieved from, http://rlwclarke.net/Theory/SourcesPrimary/HallCulturalIdentityandDiaspora.pdf

Handa, A. (2003). Of Silk Saris and Mini-Skirts: South Asian Girls Walk the Tightrope of Culture. Toronto, Ont.: Women's Press. (1-32). Retrieved from, https://books-scholarsportalinfo.ezproxy.lib.ryerson.ca/en/read?id=/ebooks/ebooks0/gibson_crkn/2010-12-16/1/10191686

Hermans, H. J. M. (2001). The Dialogical Self: Toward a Theory of Personal and Cultural Positioning. Culture \& Psychology, (7)3: 243-281. Retrieved from, https://journals-sagepubcom.ezproxy.lib.ryerson.ca/doi/pdf/10.1177/1354067X0173001

Hirsch, M. (2012a). Introduction. In the Generation of Postmemory: Writing and Visual culture after the Holocaust (pp. 1-25). New York, NY: Columbia University Press. Retrieved from, https://ebookcentral-proquestcom.ezproxy.lib.ryerson.ca/lib/ryerson/detail.action?docID=909487

Hyndman, J., \& De Alwis, M. (2003). Beyond Gender: Towards a Feminist Analysis of Humanitarianism and Development in Sri Lanka. Women's Studies Quarterly, 31(3/4), 212-226. Retrieved from https://www-jstor-org.ezproxy.lib.ryerson.ca/stable/40003328?pqorigsite $=$ summon\&seq $=1 \#$ metadata info tab_contents

Hyndman, J. (2016). Multiculturalism in Canada's Sri Lankan Tamil Diaspora. Weatherhead Centre for International Affairs: Harvard University, (30)2. Spring. Retrieved from, https://wcfia.harvard.edu/publications/centerpiece/spring2016/feature-hyndman

Kessler, A. S. and Milligan, K. S. (2017). Acculturation, Education, and Gender Roles: Evidence from Canada CEPR Discussion Paper No. DP13658. Retrieved from, http://www.sfu.ca/ akessler/wp/culture.pdf

Kernerman, Gerald. (2005). Multicultural Nationalism. Vancouver: UBC Press. Retrieved from, https://books-scholarsportalinfo.ezproxy.lib.ryerson.ca/en/read?id=/ebooks/ebooks0/gibson_crkn/2009-12-01/2/404298

Kraidy, M. (2005). Hybridity, or the Cultural Logic of Globalization. Philadelphia, PA: Temple University Press. Retrieved from, http://www.oapen.org/viewer/web/viewer.html?file=http://www.oapen.org/document/626979 
Kress, T. M., \& Lake, R. (2018). The strong poetry of place: a co/auto/ethnographic journey of connoisseurship, critically and learning. Cultural Studies of Science Education (13)4. Retrieved from, https://link-springer-com.ezproxy.lib.ryerson.ca/article/10.1007\%2Fs11422-016-9804-y

Kuo B. C. (2014). Coping, acculturation, and psychological adaptation among migrants: a theoretical and empirical review and synthesis of the literature. Health psychology and behavioral medicine, 2(1), 16-33. doi:10.1080/21642850.2013.843459. Retrieved from, https://www.ncbi.nlm.nih.gov/pmc/articles/PMC4346023/

Mehrotra, G. R. (2016). South Asian Women and Marriage: Experiences of a Cultural Script. Gender Issues (33)4. Retrieved from, https://link-springercom.ezproxy.lib.ryerson.ca/content/pdf/10.1007\%2Fs12147-016-9172-7.pdf

Nagra, B., \& Peng, I. (2013). Has Multiculturalism Really Failed? A Canadian Muslim Perspective. Religions (4)4: 603-620. Retrieved from, https://search-proquestcom.ezproxy.lib.ryerson.ca/docview/1537283967?pq-origsite=summon

Nziba Pindi, G. (2018). Hybridity and Identity Performance in Diasporic Context: An Autoethnographic Journey of the Self Across Cultures. Cultural Studies $\leftrightarrow$ Critical Methodologies, 18(1), 2331. https://doi.org/10.1177/1532708617735636

Rajasingham-Senanayake. (2001). "Ambivalent Empowerment: The Tragedy of Tamil Women in Conflict”, Women, War and Peace in South Asia. New Delhi: Sage Publications. 105-125.

Remschmidt, H. (1994). Workshop II: Psychosocial milestones in normal puberty and adolescence. Hormone Research, 41(Suppl. 2), 19-29. doi: 10.1159/000183955.

https://nsuworks.nova.edu/cgi/viewcontent.cgi?article $=3402 \&$ context $=$ tqr

Rutherford, J. (1990). Identity: Community, culture, difference. London, UK: Lawrence \& Wishart. Print.

Salant, T., \& Lauderdale, D. S. (2003). Measuring Culture: A Critical Review of Acculturation and Health in Asian Immigrant Populations. Social Science \& Medicine, (57)1. Retrieved from, https://www.sciencedirect.com/science/article/abs/pii/S0277953602003003

Satkunam, A. (2017). Not Your Mother's Culture - Second Generation Tamil Women Negotiating Trauma and Identity Through Art. Ryerson University: Master of Arts (Immigration and Settlement Studies). Retrieved from, file://Users/angeline/Downloads/Satkunam,\%20Ann\%20(2).pdf

Schalk, P. (1994). Women fighters of the liberation tigers in tamil îlam. the martial feminism of atêl palacinkam. South Asia Research, 14(2), 163-195. doi:10.1177/026272809401400203. Retrieved from, https://journals-scholarsportalinfo.ezproxy.lib.ryerson.ca/pdf/02627280/v14i0002/163_wfotlttmfoap.xml 
Singh, A. (2009). Mimicry and Hybridity in Plain English. Lehigh University. Retrieved from, https://www.lehigh.edu/ amsp/2009/05/mimicry-and-hybridity-in-plain-english.html

Sinnathurai, C. (2005). Eelam Encounters: Women in Tamil Society. Sangam. Retrieved from, https://www.sangam.org/articles/view2/?uid=1007

Sparkes, A. C. (2000). Autoethnography and Narratives of Self: Reflections on criteria in action. Sociology of Sport Journal, (17)1, 21. Retrieved from http://sfx.scholarsportal.info/ryerson?ctx_ver=Z39.882004\&ctx_enc=info\%3Aofi\%2Fenc\%3AUTF$8 \& \mathrm{rfr}$ id $=$ info $\% 3 \mathrm{Asid} \% 2 \mathrm{Fsummon}$. serialssolutions.com\&rft_val_fmt=info $\% 3 \mathrm{Aofi} \% 2 \mathrm{Ffmt} \% 3 \mathrm{~A}$ $\mathrm{kev} \% 3 \mathrm{Amtx} \% 3$ Ajournal\&rft.genre $=$ article\&rft.atitle $=$ Autoethnography $\% 20$ and $\% 20$ narratives $\%$ $20 \mathrm{of} \% 20$ self $\% 3 \mathrm{~A} \% 20$ reflections $\% 20$ on $\% 20$ criteria $\% 20 \mathrm{in} \% 20$ action\&rft.jtitle=Sociology $\% 20$ of $\% 20$ Sport\%20Journal\&rft.au=Sparkes\%2C\%20Andrew\%20C\&rft.date $=2000-01-$ $01 \&$ rft.pub=Human\%20Kinetics\%20Publishers\%2C\%20Inc\&rft.issn=0741$1235 \&$ rft.eissn $=1543-$ $2785 \&$ rft.volume $=17 \&$ rft.issue $=1 \&$ rft.spage $=21 \&$ rft.externalDocID $=704972251$ |mdict=en-US

Statistics Canada. (2019). Census Profile, 2016 Census: Toronto, City [Census subdivision], Ontario and Ontario [Province]. Retrieved from, https://www12.statcan.gc.ca/censusrecensement $/ 2016 / \mathrm{dppd} /$ prof $/$ details/page.cfm?Lang $=\mathrm{E} \&$ Geo $1=\mathrm{CSD} \&$ Code $1=3520005 \& \mathrm{Geo} 2=\mathrm{P}$ $\mathrm{R} \&$ Code $2=35 \&$ SearchText $=$ Toronto $\&$ SearchType $=$ Begins $\&$ SearchPR $=01 \& B 1=$ All $\&$ GeoLevel $=$ $\mathrm{PR} \&$ GeoCode $=3520005 \& \mathrm{TABID}=1 \&$ type $=0$

Taylor, M., \& Coia, L. (2008). Self-Study Research Methodologies for Teacher Educators. Professional Learning, (7). Retrieved from, https://www.sensepublishers.com/media/939-self-study-researchmethodologies-for-teacher-educators.pdf

Taylor, M., \& Coia, L. (2013). Uncovering our Feminist Pedagogy: A co/autoethnography. Studying Teacher Education (9)1, 3-17. Retrieved from, https://journals-scholarsportalinfo.ezproxy.lib.ryerson.ca/pdf/17425964/v09i0001/3_uofpac.xml

Tyyskä, V. (2005). Parent-teen relations in the Toronto Tamil community. CERIS. Retrieved from, https://books-scholarsportalinfo.ezproxy.lib.ryerson.ca/en/read?id=/ebooks/ebooks0/gibson_cppc/2010-08-06/3/10298889

Urban, E. L. (2008). "Bird in a cage:” Exploring transnational immigrants' identity negotiations. Western Michigan University: Master's Theses. 4098. Retrieved from, https://scholarworks.wmich.edu/cgi/viewcontent.cgi?article=5157\&context=masters_theses

Wake, R. (2018). Unspoken Barriers: An Autoethnographic Study of Frustration, Resistance and Resilience. The Qualitative Report (23)12. 2899-2919. http://ezproxy.lib.ryerson.ca/login?url=https://search-proquestcom.ezproxy.lib.ryerson.ca/docview/2159618089?accountid=13631 
Warren, J. T. (2008). Performing difference: Repetition in context. Journal of International and Intercultural Communication, 1(4), 290-308. doi:10.1080/17513050802344654. Retrieved from, https://journals-scholarsportalinfo.ezproxy.lib.ryerson.ca/pdf/17513057/v01i0004/290_pdric.xml

Weichold, K. (2010). Introduction to Mobility, Migration, and Acculturation. ISSBD (58)2. Retrieved from, https://issbd.org/resources/files/JBD_nov10.pdf

Werbner, P., \& Modood, T. (2015). Debating cultural hybridity: Multicultural identities and the politics of anti-racism (New ed., Critique Influence Change, pp. xiv-xviii). London, England: Zed Books. Retrieved from, https://books.google.ca/books/about/Debating_Cultural_Hybridity.html?id=nxFkDgAAQBAJ\&r edir_esc $=\mathrm{y}$

Williams, A. (2013). The Well-Being of Kenyan-Canadian Parents and Youth Living in Mixed Families in Montreal.” Master's Thesis, McGill University. Retrieved from, http://www.collectionscanada.gc.ca/obj/thesescanada/vol2/QMM/TC-QMM-121460.pdf. 